Portland State University

PDXScholar

\title{
Teaching figure drawing to adolescents within the context to [i.e. of] imaginative compositions, as a means of increasing artistic confidence and abilities
}

Christine Flavell Turner

Portland State University

Follow this and additional works at: https://pdxscholar.library.pdx.edu/open_access_etds

Part of the Art and Design Commons, and the Art Education Commons Let us know how access to this document benefits you.

\section{Recommended Citation}

Turner, Christine Flavell, "Teaching figure drawing to adolescents within the context to [i.e. of] imaginative compositions, as a means of increasing artistic confidence and abilities" (1982). Dissertations and Theses. Paper 3218.

https://doi.org/10.15760/etd.3209

This Thesis is brought to you for free and open access. It has been accepted for inclusion in Dissertations and Theses by an authorized administrator of PDXScholar. Please contact us if we can make this document more accessible: pdxscholar@pdx.edu. 
AN ABSTRACT OF THE THESIS OF Christine Flavell Turner for the Master of Science in Teaching in Art presented May 14, 1982.

Title: Teaching Figure Drawing to Adolescents Within the Context of Imaginative Compositions, as a Means of Increasing Artistic Confidence and Abilities.

APPROVED BY MEMBERS OF THE THESIS COMMITTEE:

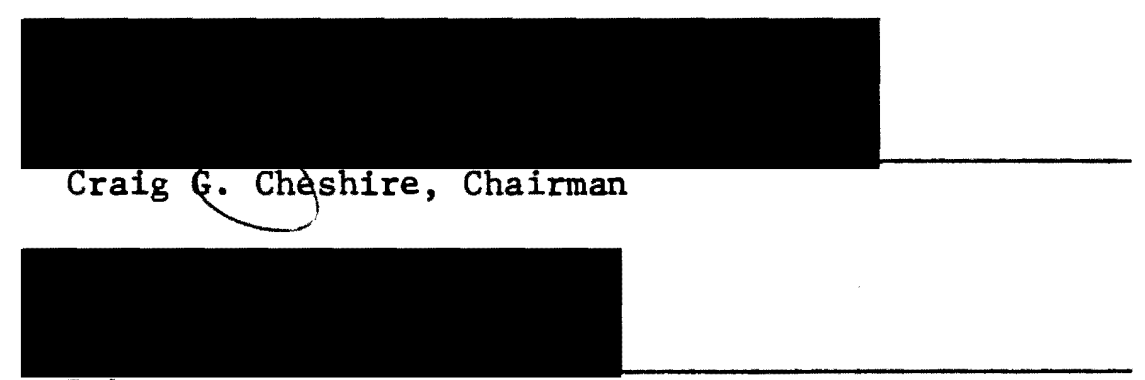

Robert Morton

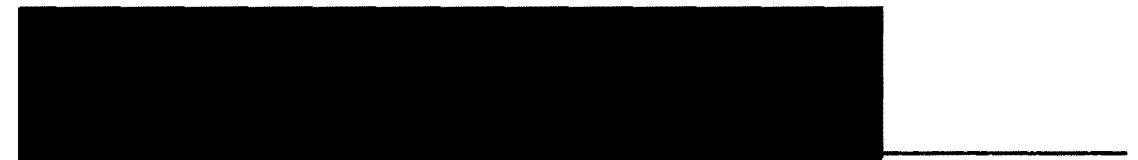

Richard Prasch

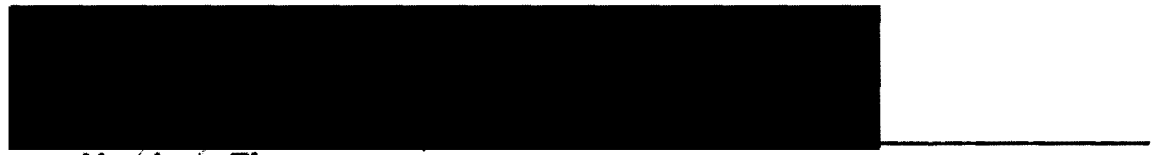

Maxiné Thomas

This thesis describes a process of teaching figure drawing to adolescents which places importance on the subjective experiences of the students. Traditional figure drawing methods emphasizing the development of visual perceptual skills are integrated with activities which are designed to secure emotional participation, and develop awareness of art as a means of expression and communication. This approach seems to 
motivate students and to reduce the anxiety usually experienced by adolescents when they are drawing the figure.

The progress of individual students has been recorded in the illustrations. 
TEACHING FIGURE DRAWING TO ADOLESCENTS WITHIN THE CONTEXT TO IMAGINATIVE COMPOSITIONS, AS A MEANS OF INCREASING ARTISTIC CONFIDENCE AND ABILITIES

by

CHRISTINE FLAVELL TURNER

A thesis submitted in partial fulfillment of the requirements for the degree of

MASTER OF SCIENCE IN TEACHING

in

ART

Portland State University 
TO THE OFFICE OF GRADUATE STUDIES AND RESEARCH:

The members of the Committee approve the thesis of Christine Flavell Turner presented May 14, 1982.

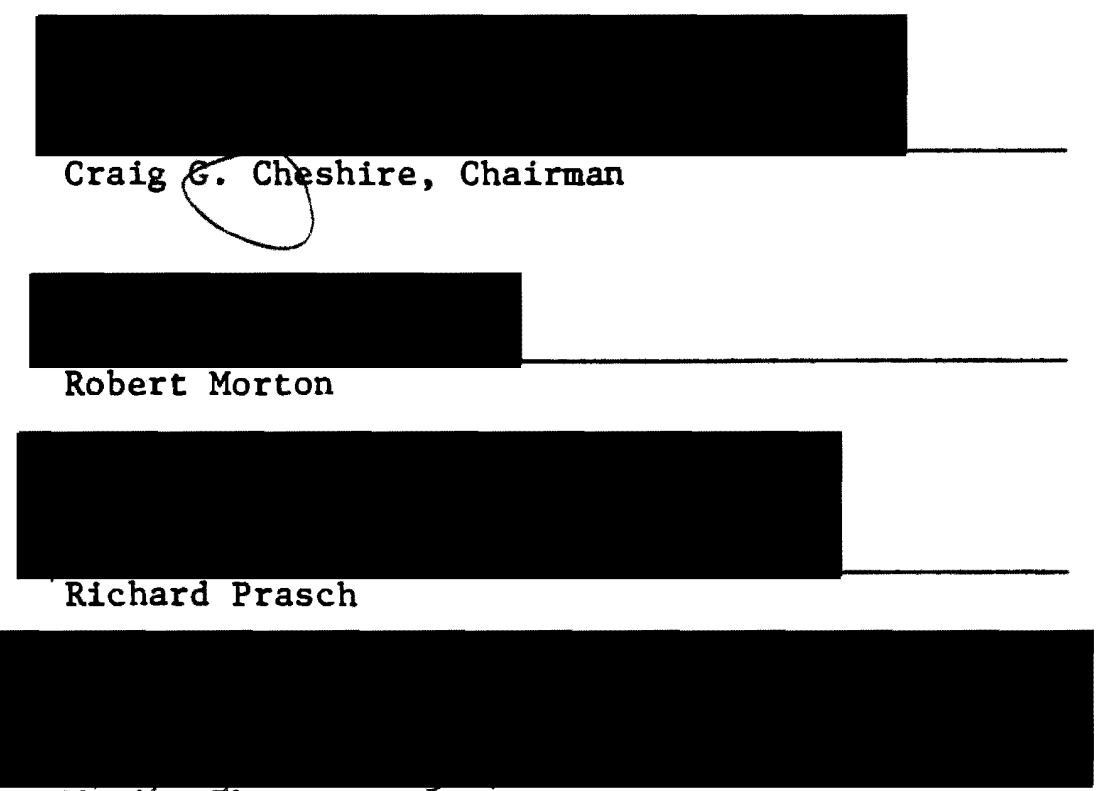

Maxine Thomas

APPROVED:

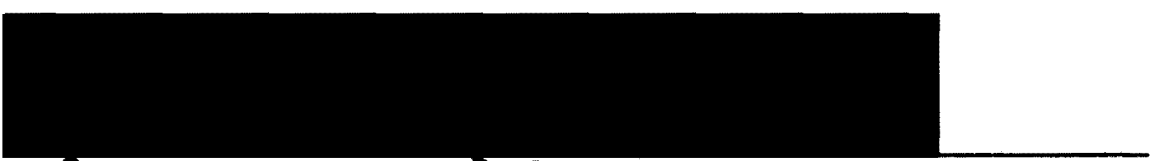

Leonard $B$. Kimbrell, Head, Department of Art

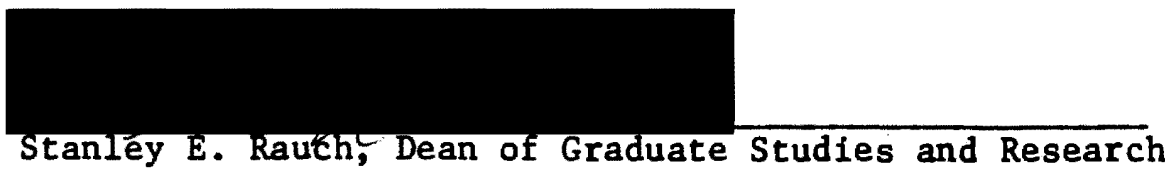


TABLE OF CONTENTS

PAGE

LIST OF FIGURES . . . . . . . . . . . . . . . . . . . . . .

CHAPTER

I INTRODUCTION . . . . . . . . . . . . . . . . .

II A DESCRIPTION OF THE TEACHING METHODS, WITH OBSERVATIONS

ON THEIR EFFECTIVENESS . . . . . . . . . . .

Project 非, first figure drawings

Project \#2, first figure drawings from a model, and introduction of gesture drawing techniques

Project \#3, gesture drawings, and compositions on a "sports" theme

Project \#4, introduction to the use of the emotive quality of gesture to express mood in drawing

Project 非, "self portraits"

Project \#6, experiencing and drawing movements

Project \#7, introduction of contour drawing, and "self portraits" using gesture to express mood

Project \#8, life sized outline drawings, and imaginative compositions based on these drawings

Project \#9, contour drawings of positive and negative spaces

Project $\# 10$, combined gesture and contour drawings

III CONCLUSIONS AND RECOMMENDATIONS . . . . . . . . . . . 42

A LIST OF WORKS CONSULTED . . . . . . . . . . . . . . . . 45

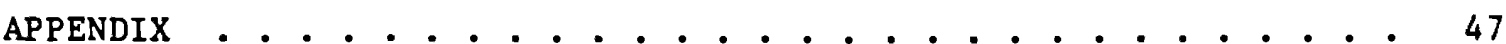

Drawings by the Author 


\section{LIST OF FIGURES}

FIGURE

PAGE

1. Schematic stage drawing . . . . . . . . . . . 7

2. Schematic stage drawing . . . . . . . . . . . . . 7

3. Contour drawing . . . . . . . . . . . . . . 8

4. "True to appearance" stage drawing . . . . . . . . . 8

5. Figure drawing from a model . . . . . . . . . . . 12

6. Figure drawing from a model . . . . . . . . . . . . 12

7. Figure drawing from a model . . . . . . . . . . . 12

8. Figure drawing from a model . . . . . . . . . . . . 12

9. First "true to appearance" stage drawing by student who drew Figure 1............... 13

10. Gesture drawing used in Imaginative composition . . . . . 13

11. Two minute gesture drawings . . . . . . . . . . . 16

12. Composition using gesture drawing showing further

development of student who drew Figures 1 and 9 . 16

13. Composition by student who drew Figures 7 and 8 . . . . 17

14. Mixed stage drawing having schematic and "true to appearance" characteristics by student who drew Figures 1,9,12.............. 17

15. Composition by student who drew Figures $7,8,13$. . . 20

16. Composition by student who drew Figures $7,8,13,15$. 20

17. Composition by student who drew Figure 4 . . . . . . . . 21

18. Composition expressing mood . . . . . . . . . . . . 21 
19. Drawing by student who drew Figures $7,8,13,15,16$. 23 20. "Self portrait" . . . . . . . . . . . . . . . . 23

21. Drawing by student who drew Figures 4 and 17 . . . . . 23

22. Drawing showing development of student who drew

Figures 7, 8, 13, 15, 16, 19 . . . . . . . . . 25

23. Mixed stage drawing with "true to appearance" figures . . 25

24. Composition showing development of student who drew

Figures 4, 17, 21 . . . . . . . . . . . . . 26

25. Contour drawing by student who drew Figure 23 . . . . . . 29

26. Contour drawing . . . . . . . . . . . . . . . . . . . . 29

27. Drawings by student who drew Figures $4,17,21,24$. . 30

28. Drawings by student who drew Figures 23 and 25 . . . . 30

29. Outline drawing . . . . . . . . . . . . . . . . 32

30. Composition by student who drew Figures $23,25,28$. . 32

31. Outline drawing . . . . . . . . . . . . . . . 33

32. Composition by student who drew Figures $7,8,13,15$

$$
16,19,22 \text {. . . . . . . . . . . . . . . }
$$

33. Contour drawing by student who drew Figures 4,17 ,

$$
21,24,27 \text {. . . . . . . . . . . . . . }
$$

34. Contour drawing by student who drew Figure $10 . . . .$. .

35. Gesture drawing by student who drew Figures 2 and 5

showing development from schematic to "true to appearance" stage . . . . . . . . . . . . .

36. Contour drawing by student who drew Figures $2,5,35$, showing development from schematic to "true to 


$$
\text { appearance" stage . . . . . . . . . . . . } 38
$$

37. Gesture and contour drawing . . . . . . . . . . . 40

38. Drawing by student who drew Figures 10 and 34 . . . . . 40

39. Drawing showing development of student who drew

$$
\text { Figures 4, 17, 21, 24, } 27 \text {. . . . . . . . . . . } 41
$$

40. Drawing showing development of student who drew

Figures 4, 17, 21, 24, 27, 39 ........... 41

41. Drawing by the Author .. . . . . . . . . . . . 48

42. Drawing by the Author . . . . . . . . . . . . . 48

43. Drawing by the Author . . . . . . . . . . . . 48

44. Drawing by the Author . . . . . . . . . . . . . . 48 
CHAPTER I

INTRODUCTION

Art education puts a premium on what is singularly particular to each person. It stresses the unique and the personal, permitting each student to listen to himself and to discover his own sources, inclinations, possibilities, and imitations. 1

The art educator who chooses to work with the adolescent age group faces a great challenge, for it is at this stage in human development that the decision is most often made to turn away from creative experiences in the visual arts. Feldman summarizes the difficulties the adolescent faces:

The adolescent's work reflects 2 contending influences: a persistent desire to express with fluency and fidelity his sensory and affective experiences, and an increased effort to represent reality as he belleves adults see 1t. But these motives are incompatible. The fluency of the child's creative expression is based on the absence of adult standards of imagery and his inability to engage in serious self criticism. Both of these (adult standards and self criticism) make their appearance at puberty. Consequently, the smooth, virtually uninterrupted process of perception, feeling, execution and aesthetic delight visible in the art of young children, yields to a considerable amount of agonizing in the creative work of adolescents. Also the polarization of aesthetic types leads to a loss of confidence on the part of haptic, or nonvisual personalities. The visual types, on the other hand, are somewhat frustrated by their inability to meet their own, now highly developed, standards of optical realism.

Teachers, realizing the need to provide adolescents with

IIrving Kaufman, Art and Education in Contemporary Culture, (New York: MacMillan), 1966, p. 33.

2E. B. Feldman, Becoming Human Through Art, (Englewood Cliffs, New Jersey: Prentice Hal1), 1971, pp. 114, 115. 
assignments at which they can succeed and take pride in, have used a variety of approaches ranging from focusing on crafts, or non representational styles of painting, drawing and sculpture, to providing intensive training designed to develop the student's technical and observational skills as applied to representational work. Since my experience with adolescents has led me to believe that they most value realism in art, I have favored the latter approach. However teaching drawing to adolescents using the methods one would use in a figure drawing class at the college level presents many problems. The difficulties intrinsic in drawing the figure, and the intensive focusing on these difficulties frequently causes more frustration than satisfaction. In adolescents, this may easily contribute to increased self consclousness, reduction in spontaneity, and a desire to avoid any further such embarrassing fallures in front of the peer group.

The purpose of this research was to develop a way of introducing figure drawing which would be relatively non threatening and would help students to retain the excitement of the creative experience; to see art as a means of personal expression and growth, a way of better understanding themselves and the world around them, and an effective method of communication. This seemed to call for a student centered approach, as defined in the 1972 N.A.E.A. publication "Art Education: Senior High School",

Based primarily upon each individual's cultural, psychological and physical needs and interests, and upon his level of cognition, emotional reaction and perceptual sensitivity. 3

${ }^{3}$ Art Education: Sentor High School, (Reston, Virginia: National Art Education Association), 1972, p. 21 . 
My plan was to introduce students to the same techniques and information they would receive in a more traditional beginning figure drawing class, but within a structure providing opportunities for the students to succeed, in their own terms. Adolescents working independently often choose to draw themes from the imagination which reflect their growing interest in their environment, social causes, interpersonal relationships, and their increasing awareness of their own feelings. They usually integrate figures in such works, and when the entire focus is not on the figure they seem to find it less intimidating to deal with. If they are satisfied with some aspect of their compositions, they tend to be less embarrassed by their evident inadequacies at figure drawing. Thus by suggesting the use of themes and focusing attention on them, and on the meanings seen in the work, I hoped to guide students towards a valuing of art as a means of communication and self expression. By not emphasizing the visual perceptual approach heavily, in the beginning, I hoped to establish a "safe" environment in which students would experience less of the anxiety and inhibitions adolescents usually feel when they begin working with the figure and make the inevitable mistakes. I believed that this approach would lead to increased involvement and confidence, and greater motivation to continue working. I hoped to see a synthesis of form and content in the students' work, realized as convincing graphic statements of a personal nature about the subject, and showing development of visual perceptual skills.

The twelve adolescents with whom I did the research for this paper were thirteen to sixteen years old, male and female. Half of them had 
studied art in a post elementary school situation. Students ranged in I.Q.s from dull normal to high average, according to results of recent WISC tests. They had all expressed interest in participating in ten weekly art classes of one hour's duration. The content of the class work had not been discussed. 


\section{A DESCRIPTION OF THE TEACHING METHODS, WITH OBSERVATIONS ON THEIR \\ EFFECTIVENESS}

\section{PROJECT \#1: FIRST FIGURE DRAWINGS}

During the first meeting we spent time talking about the students' values in relation to art. They unanimously agreed that they most admired realism, and said that what they would like to be able to do we11 was "draw people". This was consistent with my past teaching experiences with adolescents. The students were very concerned about the difficulties figure drawing presented, and they all expressed lack of confidence in their abilities to succeed. I made no attempt to minimize the difficulties involved. In order to make an initial assessment of the students' levels of visual perceptual development, I needed to see some figure work. I proposed that they sit quietly for a few minutes and imagine themselves to be in a favorite place, then draw that place. As they became involved in the work, I asked them to draw themselves in their pictures. Possibly because the emphasis was on the place rather than the figure, the suggestion did not meet any verbal resistance. Students resorted to a variety of techniques in representing the figure: cartoon figures, stick figures, 3 students did schematic stage drawings, and 5 students did "true to appearance" drawings. Those who used cartoon and stick figures may have been attempting to avoid anxiety caused by possible failure, by falling back 
on "formula" styles which would be difficult to criticize. I could not assess the level of development of those students. The fact that only 5 showed definite evidence of having reached the "true to appearance" stage was consistent with Lark-Horowitz'4 finding that fewer than half of 15 year olds reach the "true to appearance" stage in their drawings. In making comments about these first drawings, I was careful to be nonjudgemental about the figure work, and dealt with the content, and its emotional and social implications, rather than the plastic qualities of the work. By placing emphasis on the theme it was possible to be supportive and positive about some aspect of each student's work. The purpose of using this approach was to relieve anxiety in the students and to develop some awareness of art as communication. While most of them voluntarily expressed awareness of their poor figure drawing skills, they were able to take some pride in other aspects of their work, even if it was only in sharing feelings about a favorite place.

${ }^{4}$ Betty Lark-Horovitz, Hilda Lewis, Mark Luca, Understanding Children's Art for Better Teaching, 2nd ed., (Columbus. Ohio: Chas. E. Merrill, 1973, p. 15. 


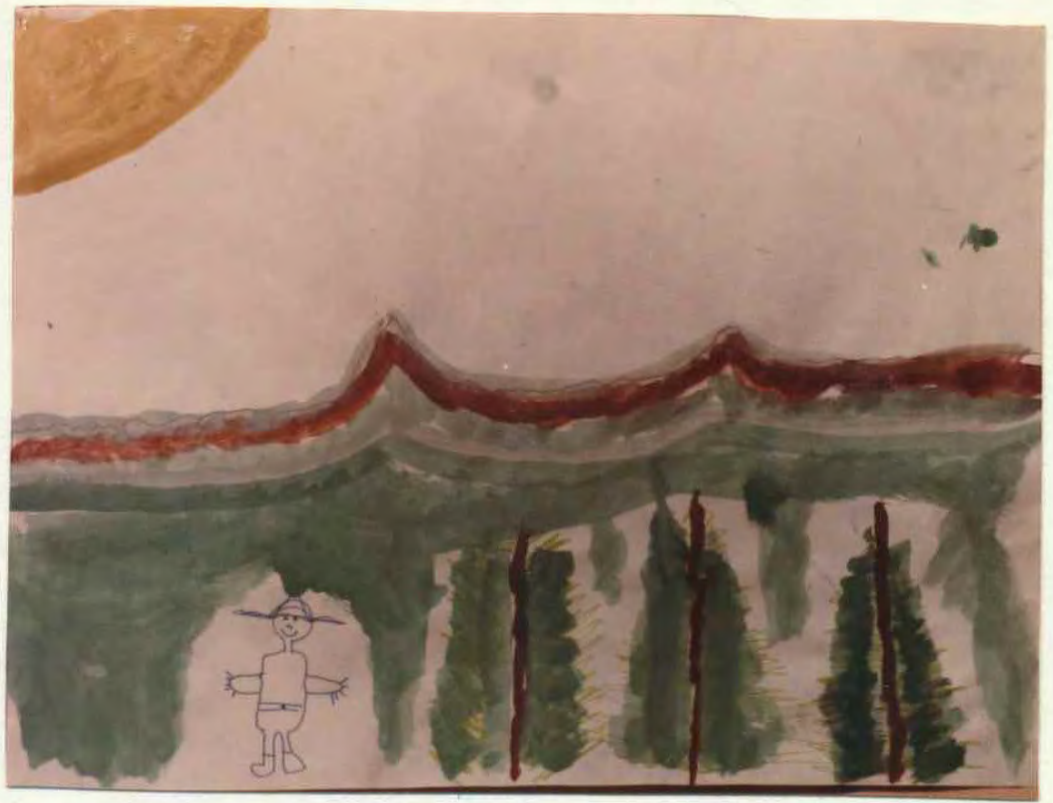

Figure 1. Schematic stage drawing.

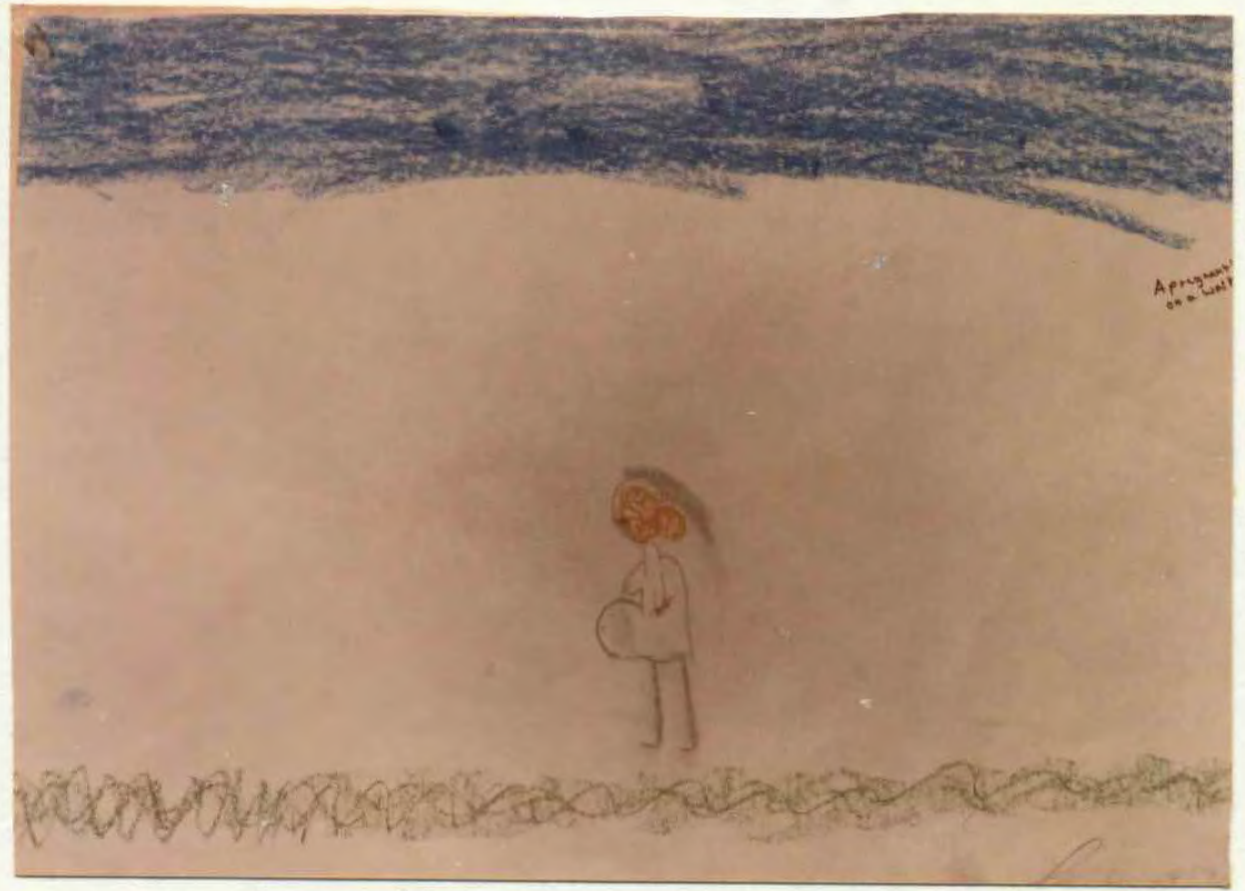

Figure 2. Schematic stage drawing.

SOME RESULTS OF PROJECT 非, FIRST FIGURE DRAWINGS 


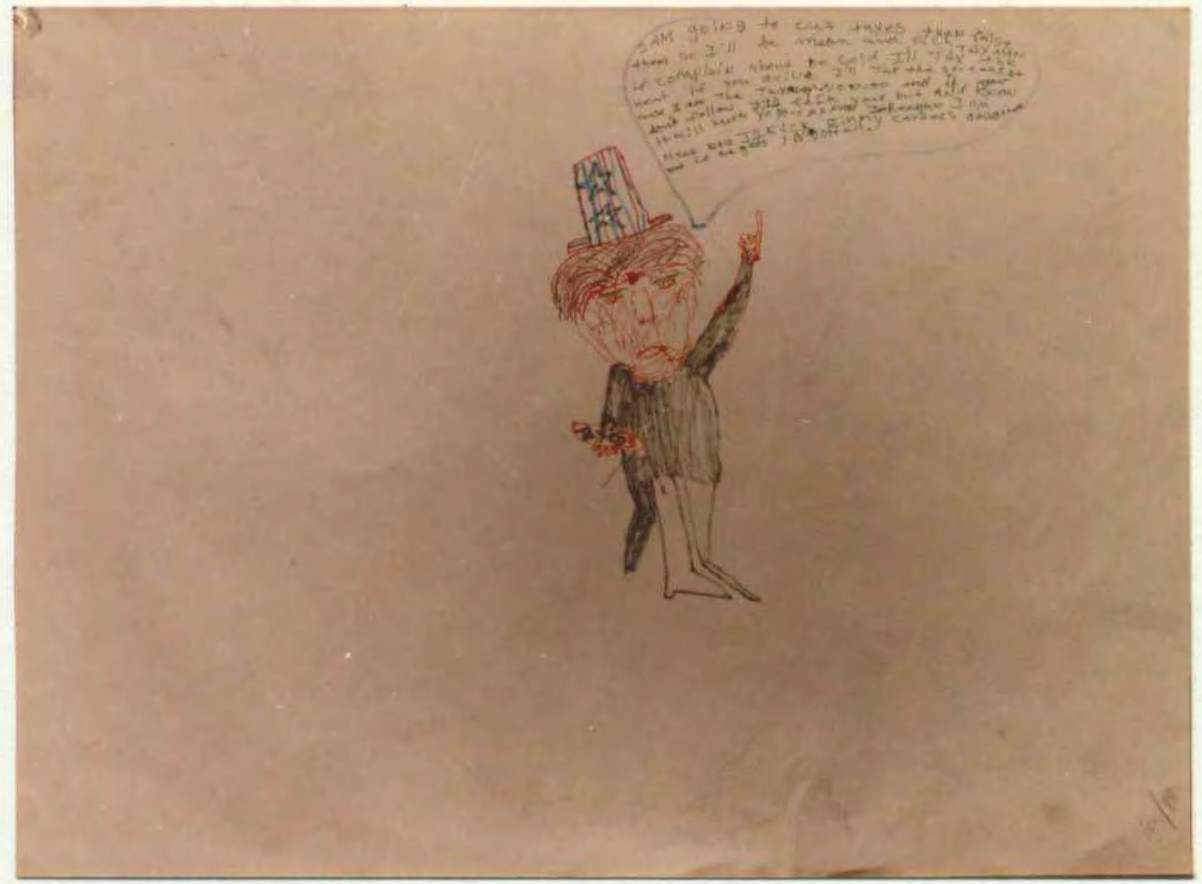

Figure 3. Cartoon drawing.

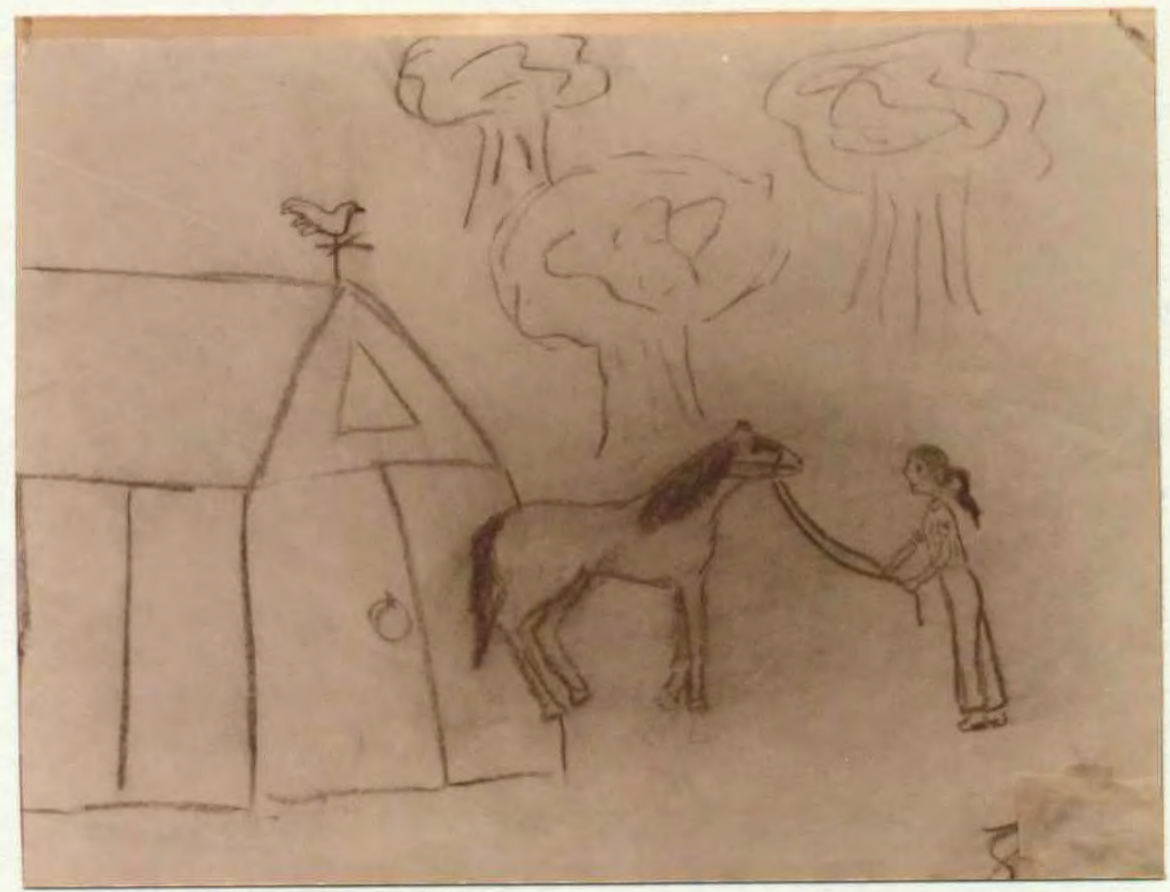

Figure 4. "True to appearance" stage drawing. SOME RESULTS OF PROJECT \#1, FIRST FIGURE DRAWINGS 


\section{PROJECT \#2: FIRST FIGURE DRAWINGS FROM A MODEL}

INTRODUCTION OF GESTURE DRAWING TECHNIQUES

The second class started with a discussion of what the group would be doing for the next nine weeks. I asked for suggestions of topics the students would like to draw. Without exception, the topics dealt with subjects relevant to their lives, e.g. rock climbing, horseback riding, feelings such as happiness, anger. This was consistent with LarkHorovitz' 5 findings that adolescents consistently respond most positively to the subject matter in paintings which relate to life experiences. Sports were mentioned frequently and seemed to be a good starting point. The subject of drawing people involved in sports was raised. This brought out some expressions of self doubt. I accepted these and assured the students that even experienced artists have difficulty with the figure. I mentioned that I had some tips on the subject which I would share with them during our sessions, and said that if they worked, they would be pleased with their progress. They all agreed to try, and to model for each other. The process of obtaining the students' commitment to the class is quite important; a student with no investment who expresses a lot of negativity can impede the progress of others. In order to provide material for further assessment of their work I wanted the students to draw from a model. Two students each took seven minute poses, and the class drew them. The results were not

5Lark-Horovitz, Lewis, Luca, Understanding Children's Art for Better Teaching, p. 214, 215. 
unlike those of the previous week - cartoons, schematic drawings, idealized versons of the artist bearing little if any relationship to the model. Two students ignored directions to draw the whole figure and instead drew heads. Those who studied the models and attempted to draw them in a "true to appearance" manner made very small figures indicating lack of confidence. Students focused on details such as eyelashes, and had little success dealing with proportions. In short, they demonstrated all of Goldstein's "Perceptual Defects".6 I made no comments about their work. There was a general atmosphere of dissatisfaction in the class.

I had decided to introduce them at this point to gesture drawing, using the broad side of the charcoal. This technique helps students avoid sequential assembly, and aids them in seeing the figure as a whole mass consisting of related parts. I demonstrated the technique, working rapidly from a model. The students, seeing the simplicity and apparent ease of the method were eager to try. They spent the next ten minutes doing one or two minute drawings. They verbally expressed enjoyment in this experience, and even those students who were at the schematic stage were able to work at a crude "true to appearance" stage. Students remarked on how all the drawings looked similar. This seemed reassuring to those of lesser abilities. In the last fifteen minutes of the class, each student chose one gesture drawing and redrew it using the same technique, within the context of a sports picture, or other subject of his or her choosing. The model was available to resume poses upon

6 Nathan Goldstein, The Art of Responsive Drawings, (Englewood Cliffs, New Jersey: Prent1ce Hal1), 1973, PP. 309-312. 
request. At this point students who had abandoned the schema showed a strong tendency to return to it. Regression to the schematic stage occurred frequently among students who started at that level, with quick gesture drawing being most helpful to them in terms of development. At the end of the second class I commented on the drawings' content, and pointed out the work of each student which best captured the movement of the model. Increased awareness of proportions, mass and movement was evident from the point at which the gesture drawing technique had been introduced. 


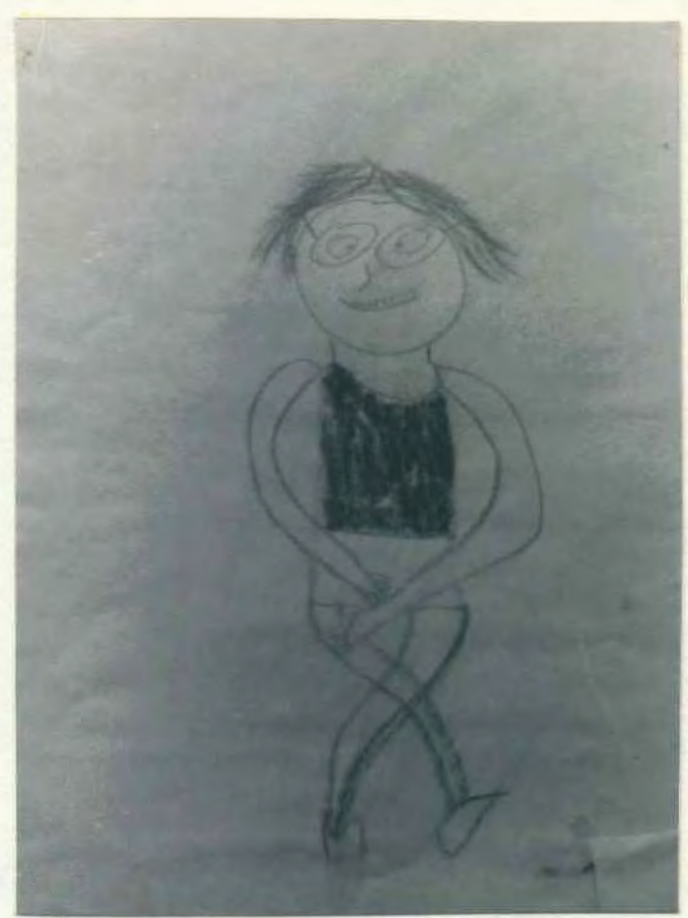

Figure 5. Figure drawing from a model.

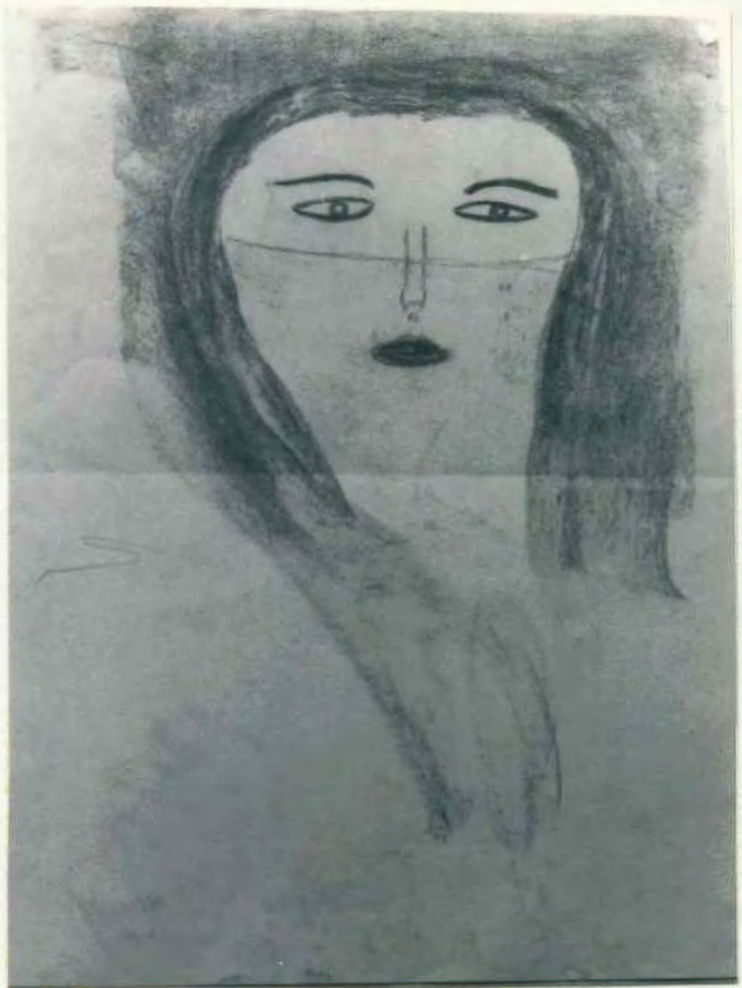

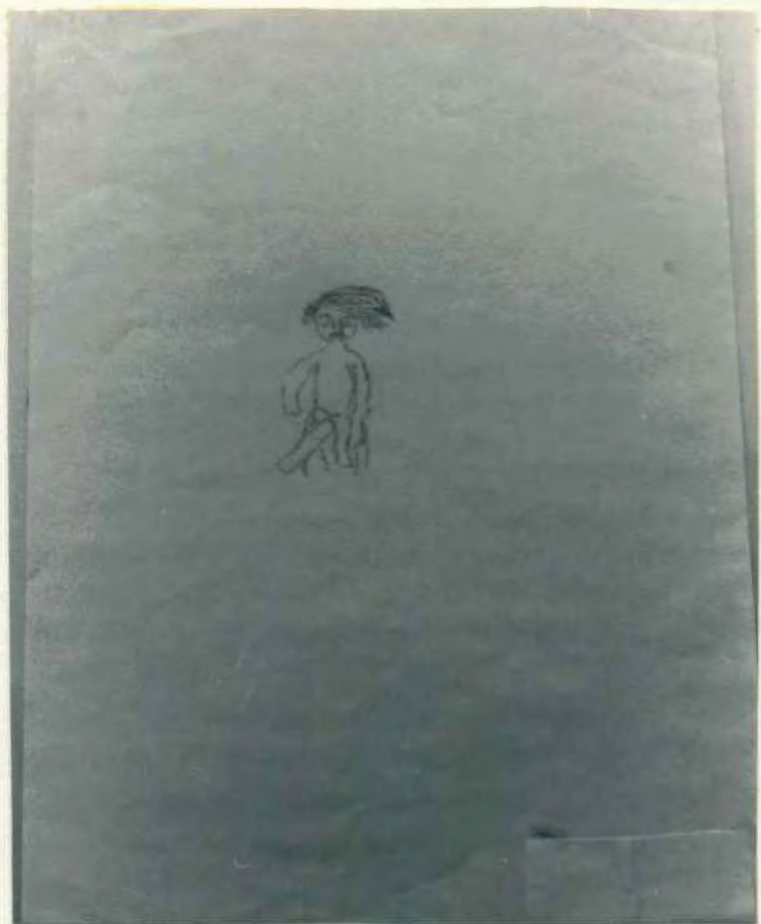

Figure 6. Figure drawing from a model.

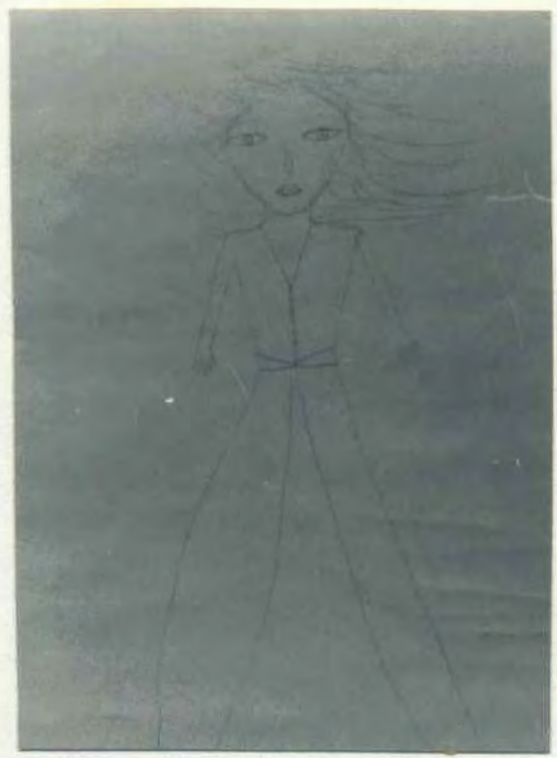

Figure 8. Figure drawing from a model.

Figure 7. Figure drawing from a model.

SOME RESULTS OF PROJECT \#2, FIRST FIGURE DRAWINGS FROM A MODEL 


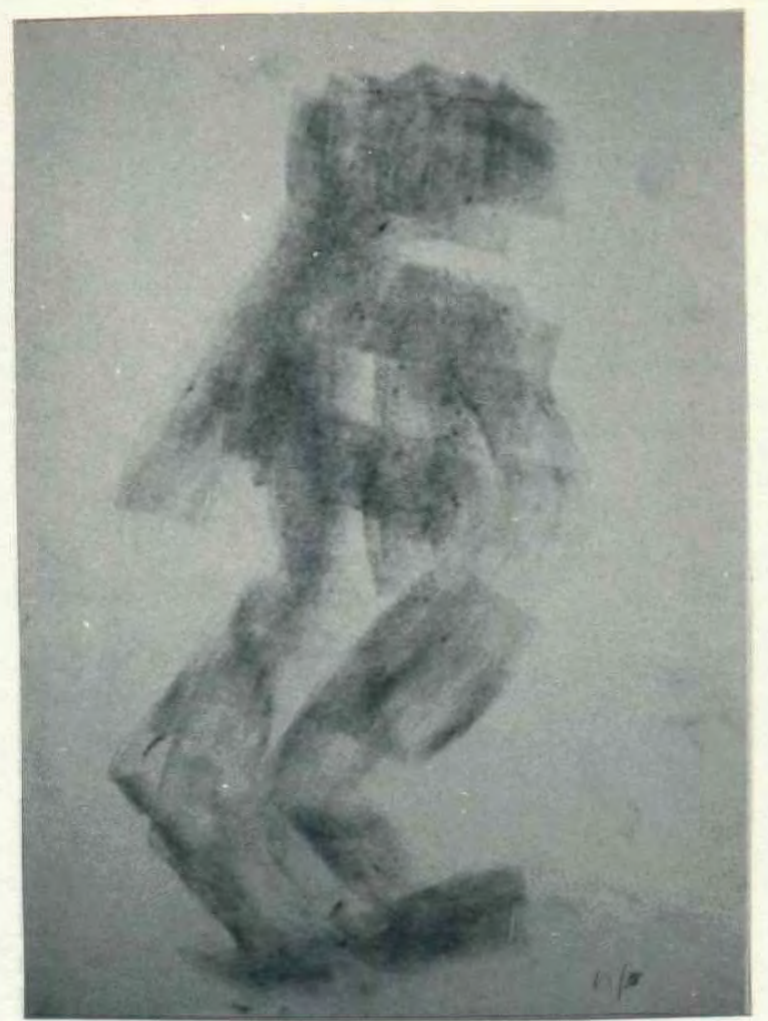

Figure 9. First "true to appearance" stage drawing by student who drew Figure 1 .

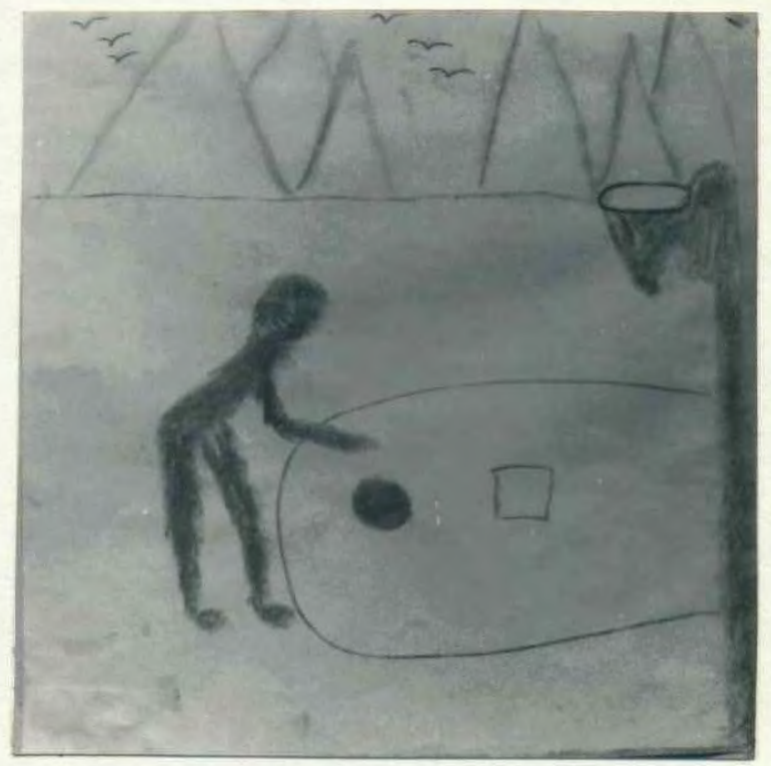

Figure 10. Gesture drawing used in imaginative composition.

SOME RESULTS OF PROJECT $\$ 2$, FIRST GESTURE DRAWINGS 
PROJECT \#3: GESTURE DRAWINGS, COMPOSITIONS

ON A "SPORTS" THEME

The third class began with a discussion of topic. Again, sports was the choice of the majority. The model took elght two minute poses relating to the major topic, and students did gesture drawings. Before each quick sketch, I pointed out the major movements of the model. I also began making observations and suggestions about proportions and movements to the more visual students. Following the format established in the second class, each student selected one or more drawings to use In the more developed work. Students who were doing both "true to appearance" sketches and schematic drawings were asked individually to compare the two types of drawings and Identify the one which looked more real. They invariably identified the gesture drawings, and were encouraged to do their longer work using the same technique. I kept critical comments low key, and focused on the themes in the students' final compositions. View finders and sighting techniques were introduced at this class. The more visual students grasped the concepts and used them periodically throughout the remaining classes. During this class the students became excited about their ability to make quick sketches which looked "true to appearance". They became quite demanding of the model, wanting their favorite poses resumed, and wanting the poses to correspond accurately with their quick sketches. Some students suggested poses and took the poses themselves to show the model. This helped increase empathy with the model. The students worked 
cooperatively and there was no inappropriate, distracting communication between the model and the other students. A variety of media was available during this class for use in the more developed work. This included crayon, cray-pas, pastel and paint. As exploration of media was not one of the goals of the course, it was not promoted. When students chose an unfamiliar medium its properties were briefly discussed. The students did not want to give up their medium of success - charcoal - and most of them completed their longer works in that medium. A few students chose to combine pastel with charcoal. Students did not attempt, in this class, to move away from the general to the particular. Details were largely ignored, with students preferring to complete several works of a general nature. 


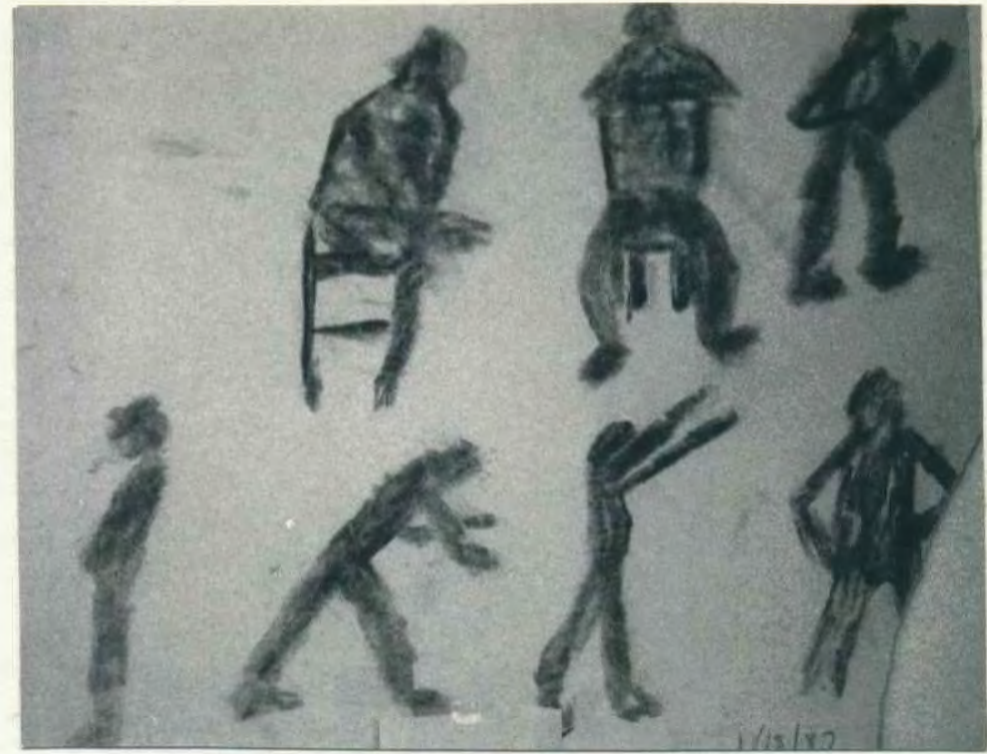

Figure 11. Two minute gesture drawings

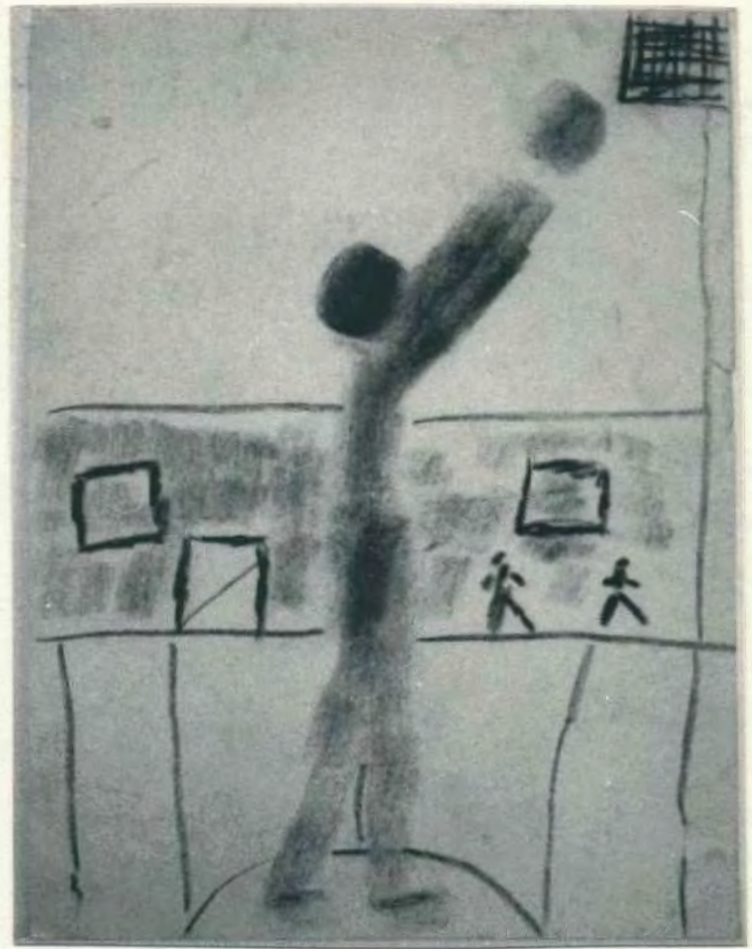

Figure 12. Composition using gesture drawing showing further development of student who drew Figures 1 and 9 .

SOME RESULTS OF PROJECT 非, GESTURE DRAWINGS AND COMPOSITIONS ON "SPORTS" THEME 


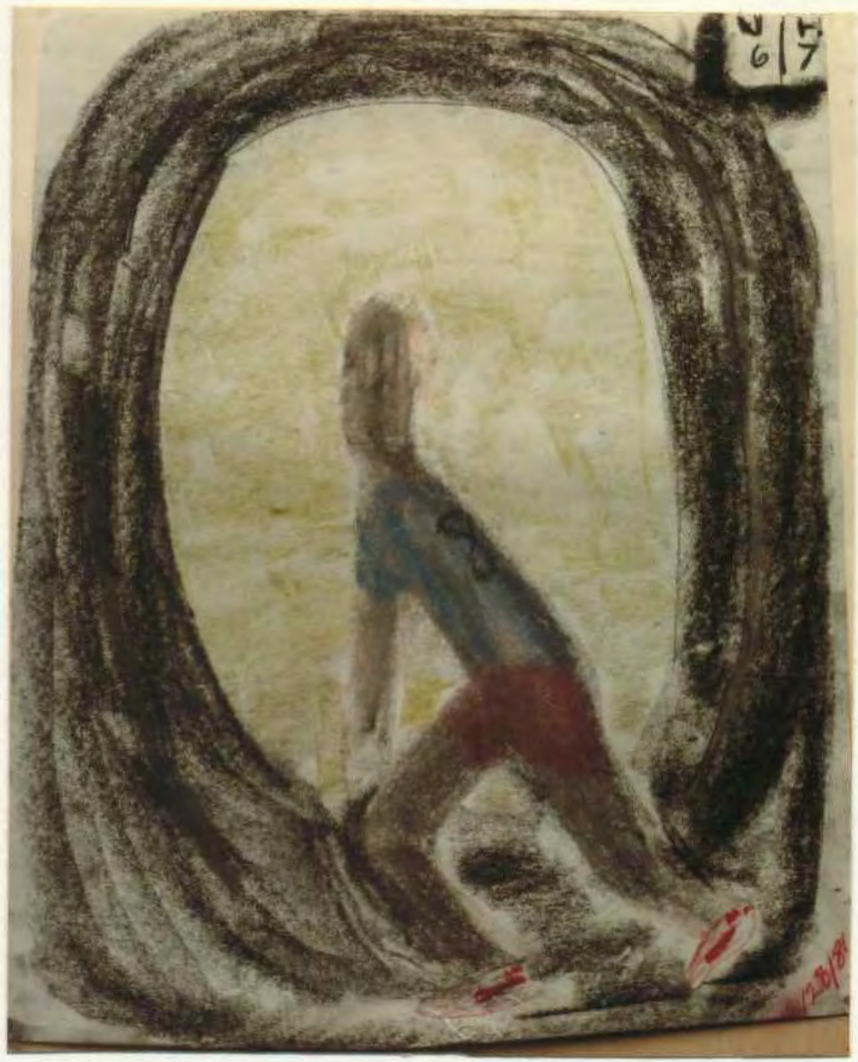

Figure 13. Composition by student who drew Figures 7 and 8 .

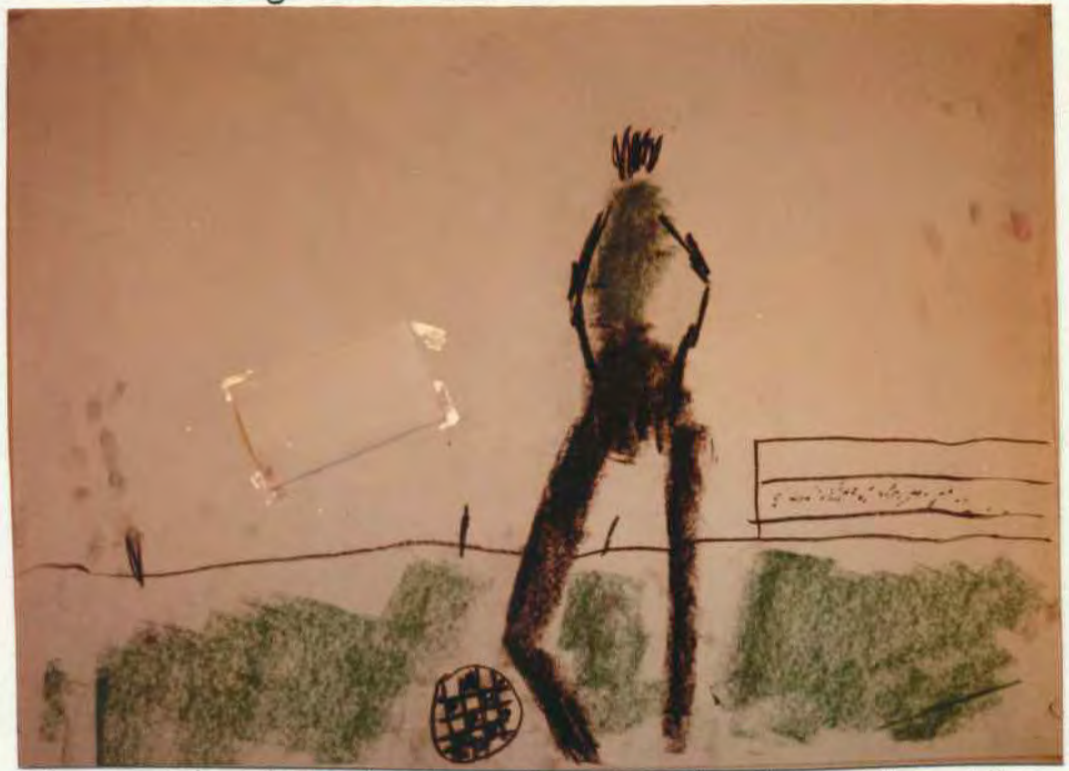

Figure 14. Mixed stage drawing having schematic and "true to appearance" characteristics by student who drew Figures 1, 9, 12 .

SOME RESULTS OF PROJECT 非, GESTURE DRAWINGS AND COMPOSITIONS ON "SPORTS" THEME 


\section{PROJECT 非: INTRODUCTION TO THE USE OF THE EMOTIVE QUALITY OF GESTURE TO EXPRESS MOOD IN DRAWING}

In the fourth week the opening discussion centered on how our bodies express feelings. Students were asked to identify moods and express them through body language in front of full length mirrors. They were able to do this without embarrassment, and the model assumed the poses they requested, for quick gesture drawings. Students then agreed on the poses they wanted repeated, and working from the gesture drawings and the model, developed compositions which were essentially self portraits expressing mood. One student also used sketches she had made during the previous week. The work done in the fourth week was more complex, sometimes having several people in the compositions. The centering on feelings engaged the students' interest and helped make them aware of the emotive qualities of gesture. As Goldstein said, "If drawings are to convey some emotive temperament the artist must first discern it in what he observes or envisions."7 A group discussion of the feelings in the pictures aided in developing the students' awareness of art as a valid means of self expression and an effective means of communication. Lark-Horovitz suggests that drawing is abandoned by children when it becomes inadequate for the delineation of experience and when words become a more useful avenue of communication. 8 This

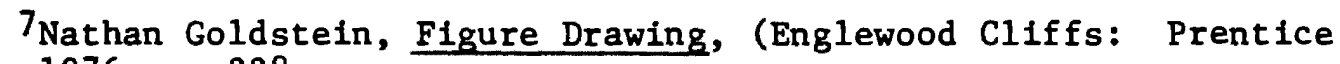
Hal1), 1976, p. 228 .

${ }^{8}$ Lark-Horovitz, Lewis, Luca, Understanding Children's Art for Better Teaching, p. 16. 
class was successful in terms of students focusing on content as well as form, they were able to see that their work had succeeded on a level of human understanding and communication. I theorized that by becoming aware of their abilities to evoke understanding in others through their art they would feel less inhibited, more sure of themselves, and more willing to take risks in their work. 


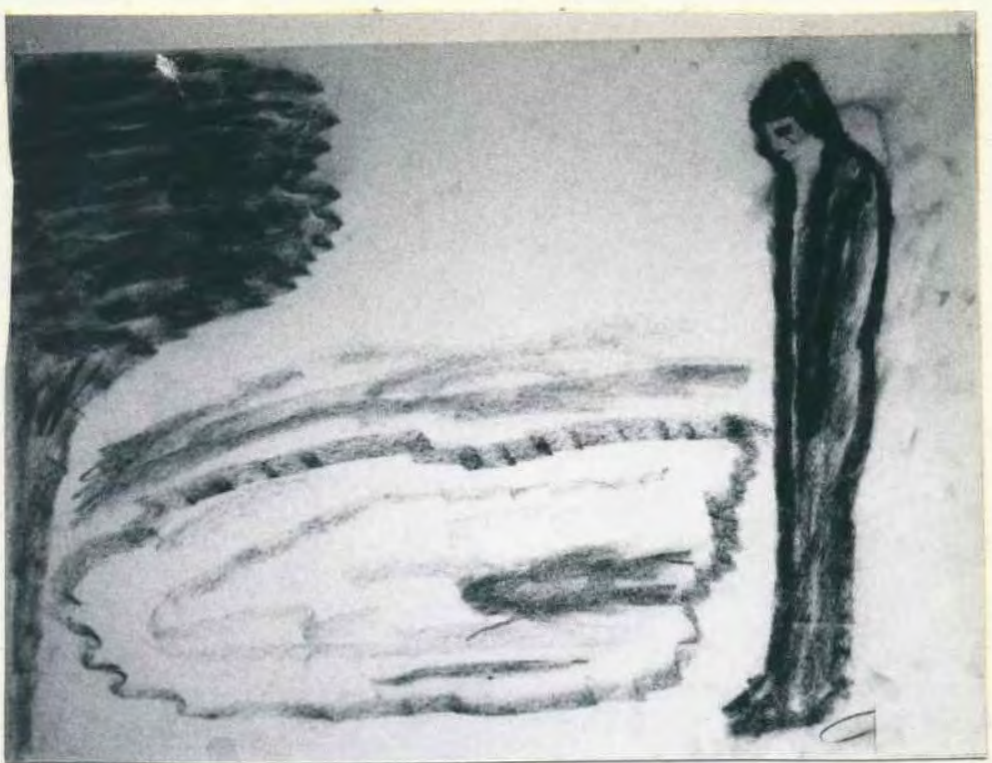

Figure 15. Composition by student who drew Figures 7, 8, 13.

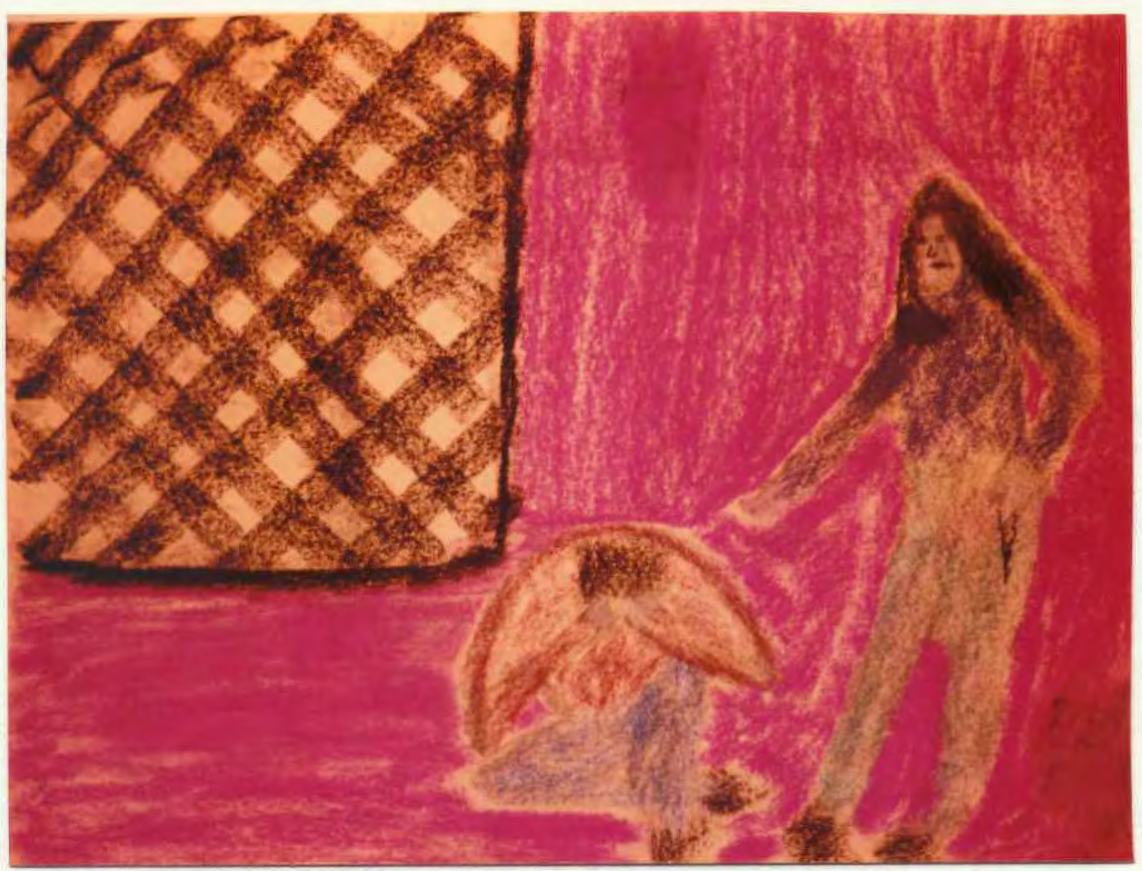

Figure 16. Composition by student who drew Figures 7, $8,13,15$.

SOME RESULTS OF PROJECT \#4, DRAWINGS USING THE EMOTIVE QUALITIES OF GESTURE TO EXPRESS MOOD 


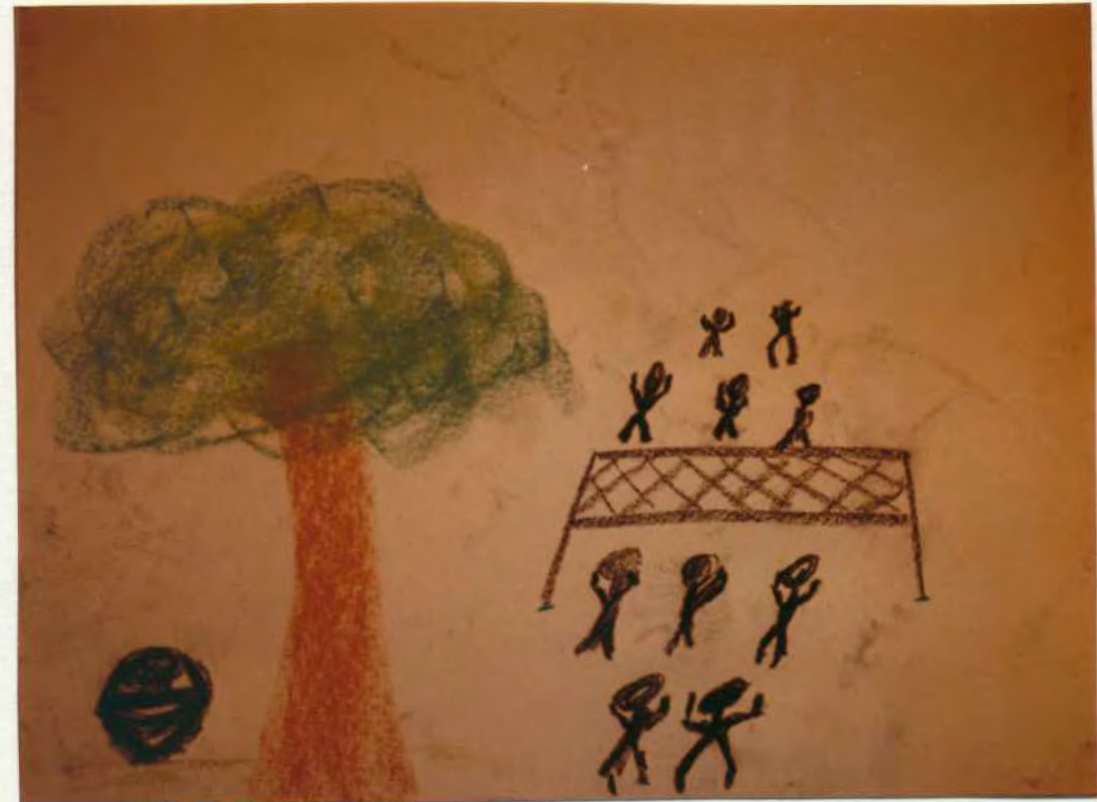

Figure 17. Composition by student who drew Figure 4 .

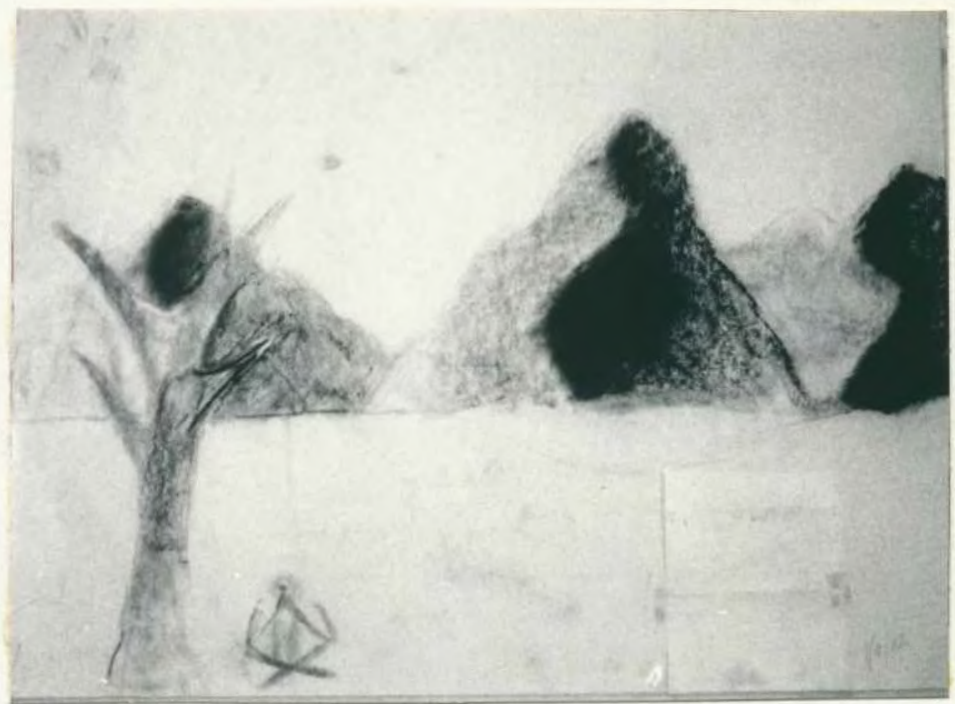

Figure 18. Composition expressing mood. 


\section{PROJECT 非: "SELF PORTRAITS"}

In the fifth week I suggested students do self portraits, as they are now or as they would like to be in a few years. This was recelved with much self conscious giggling. We started the class with gesture drawing exercises, then students were encouraged to use full length mirrors and pose for themselves. I suggested they also use each other for models. Unlike the previous week, not many of the students used themselves or others as models and the results reflected a lack of concern with the figure, including a return to schematic drawing and stick figures on the part of some students. The work of others showed a concern with idealization of self in compliance with stereotypical images as promoted by mass media. My conclusions from this class are that adolescents need more structure when dealing with a subject involving "self". They need to be guided away from objectifying themselves, away from their concern with superficlal appearances, and attempts to Impress one another, and towards awareness of their Inner feelings. This week's work was unsuccessful in every way. I kept my comments low key in an effort to avoid students feeling the need to put up defenses. 


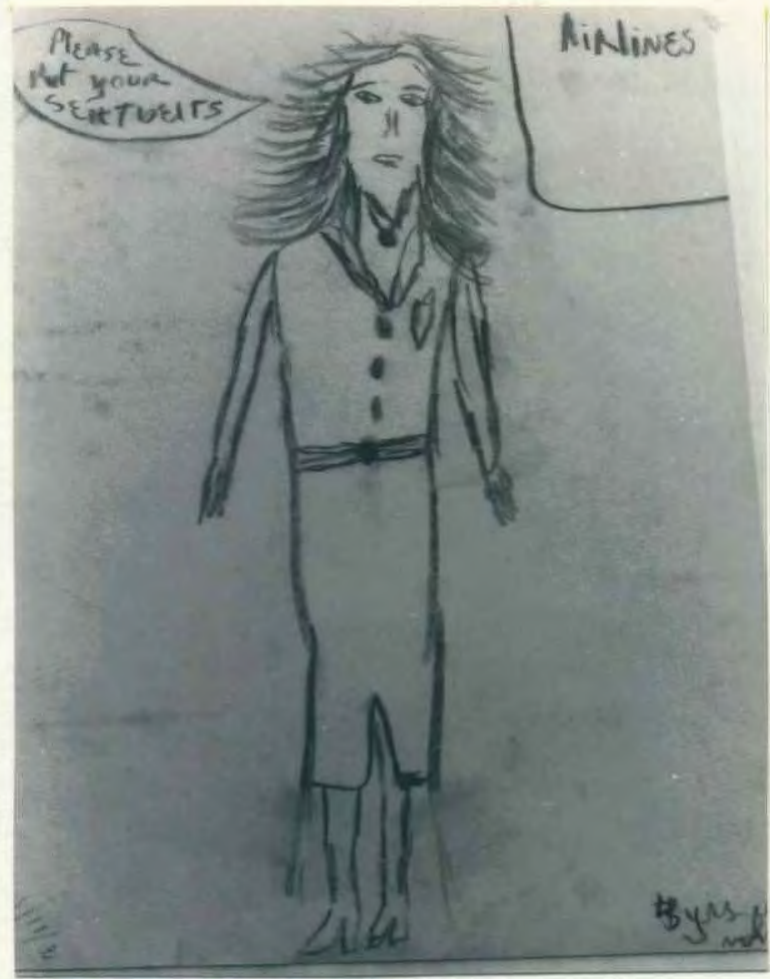

Figure 19. Drawing by student who drew Figures 7, 8, 13, 15, 16 .

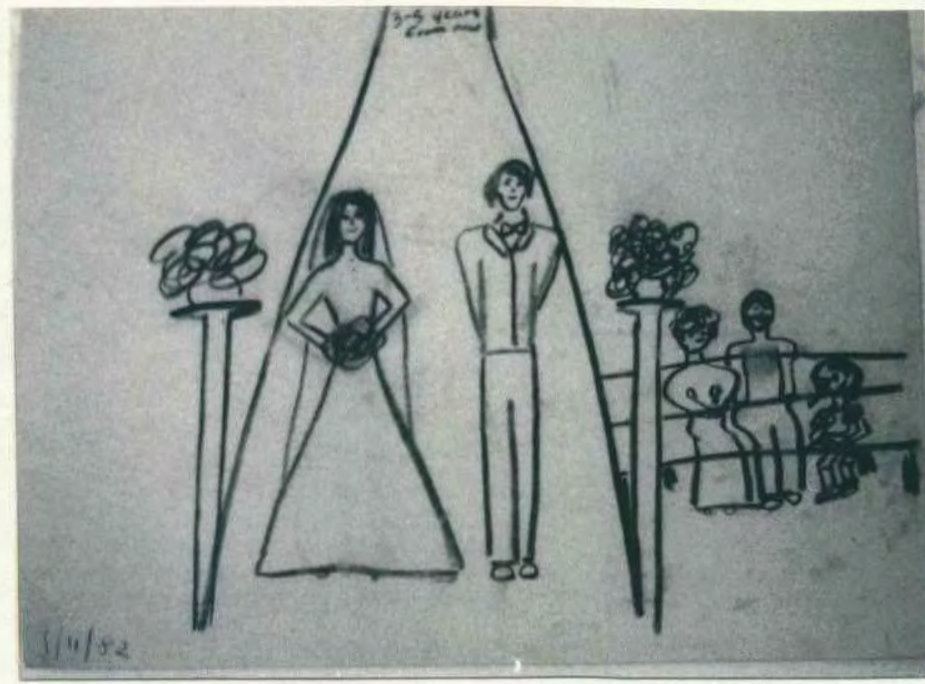

Figure 21. Drawing by student who drew Figures 4 and 17.

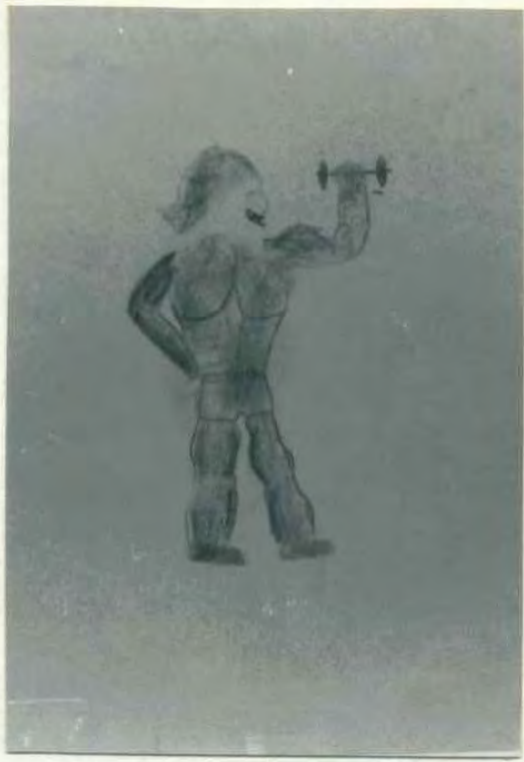

Figure 20. "Self portrait" 


\section{PROJECT 非: EXPERIENCING AND DRAWING MOVEMENTS}

In the sixth week in order to assist students to focus on movements again, we started with gesture drawings, then I asked them to walk around the room and jump, crouch, dance or move in any way they felt 11ke, and to be aware of how their bodies felt as they moved. The purpose of this was to aid them in feeling the energy involved in the gesture in the sense that Goldstein referred to when he wrote, "The emotive energy of gesture cannot be seen until it is experienced - it must be felt."9 The students' task was to draw a figure or figures in movement within an imaginative composition. Each student chose certain movements, repeated them, tried "freezing" in position and thinking about how their bodies felt, looked at themselves in movement in front of mirrors, and observed peers making the same movements. The self consciousness evident during the fifth class was not present this week. The group interaction and the physical activity engaged their interest and seemed to stimulate their imaginations. Most of the students relied on gesture drawing. Some of the more visual students introduced outlines and detalls, but with evidence of more accurate observation than during the previous week. The drawings had personal expressive qualities, and students were beginning to experiment with a variety of media.

${ }^{9}$ Nathan Goldstein, The Art of Responsive Drawing, p. 2. 


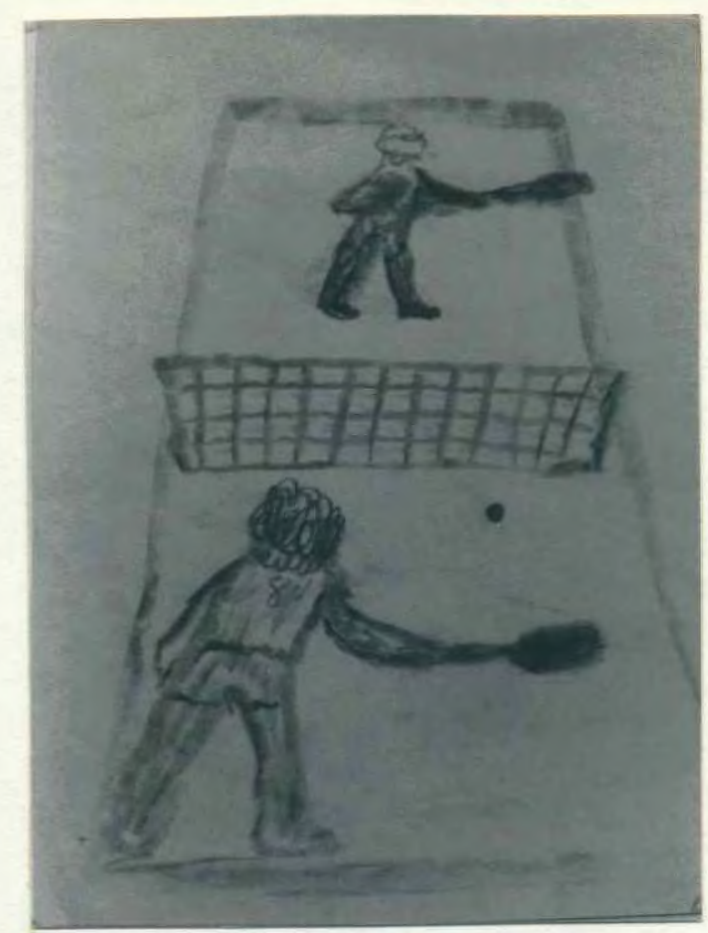

Figure 22. Drawing showing development of student who drew Figures 7, 8, 13, 15, 16, 19.

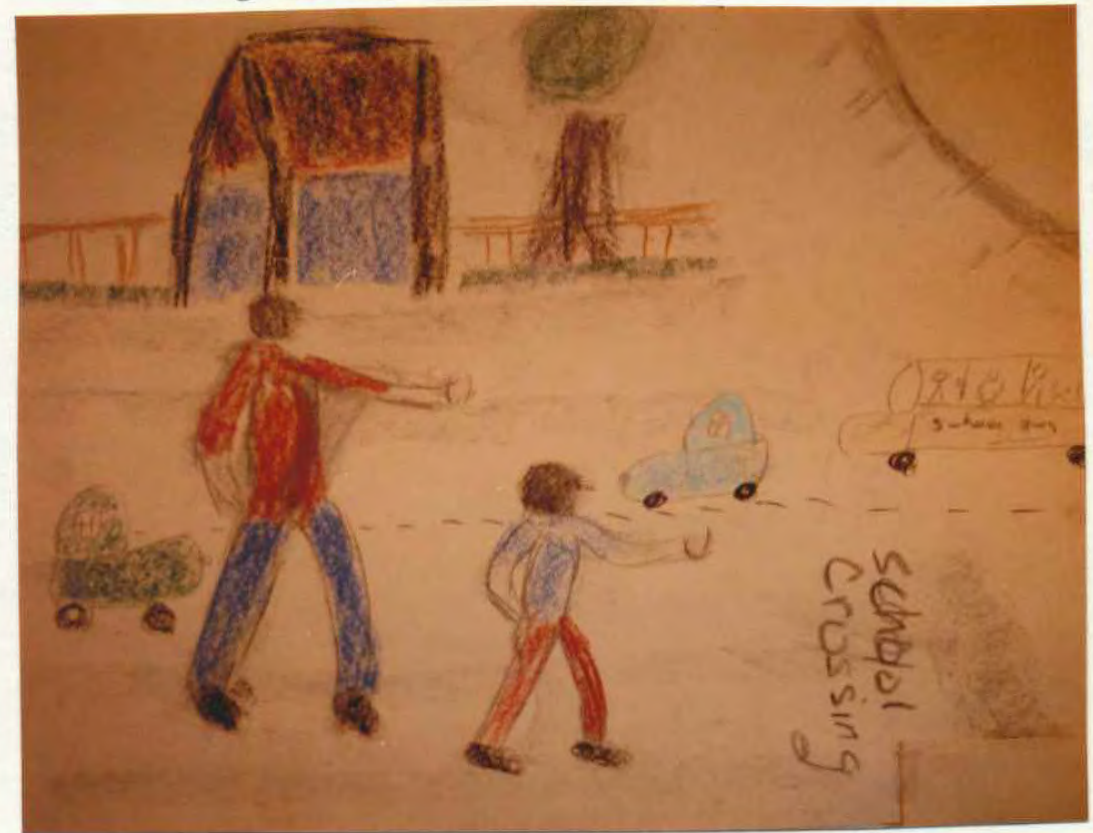

Figure 23. Mixed stage drawing with "true to appearance" figures.

SOME RESULTS OF PROJECT \#6, DRAWINGS OF MOVEMENTS WHICH STUDENTS EXPERIENCED 


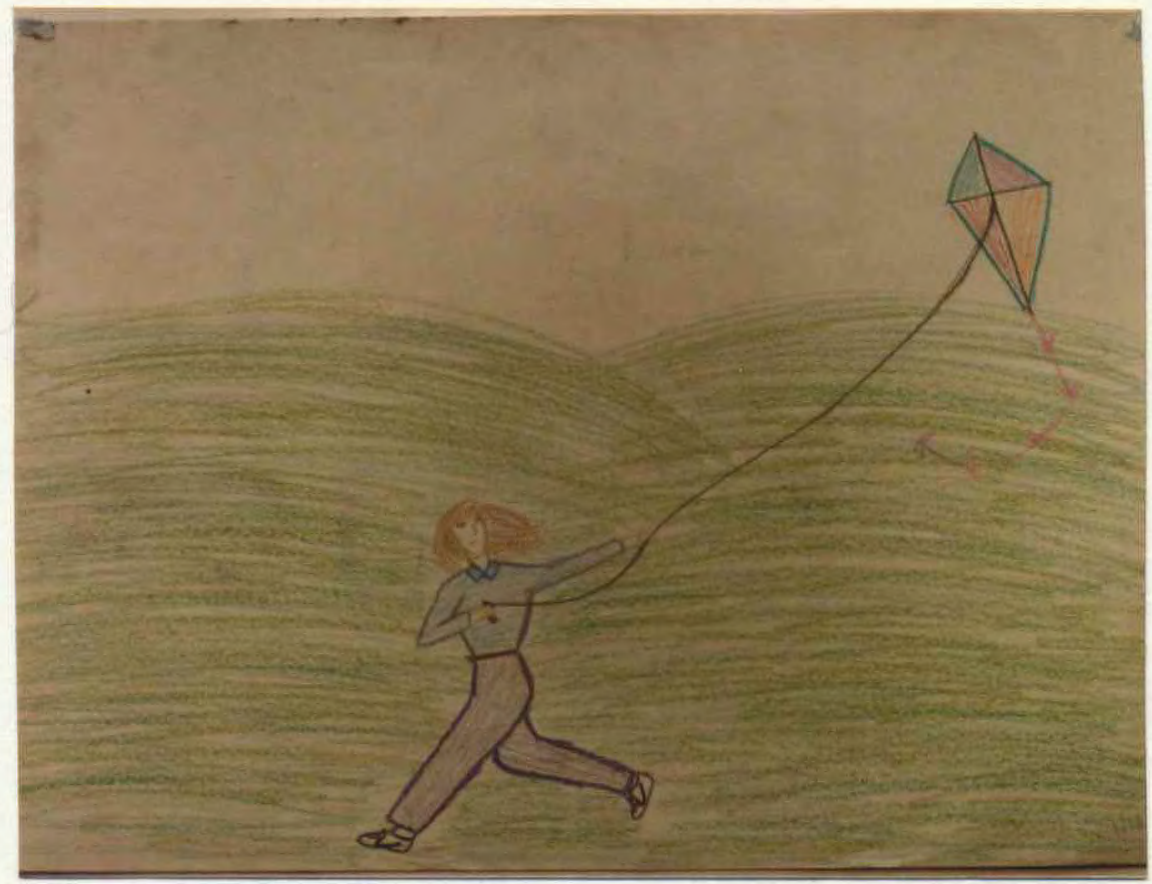

Figure 24. Composition showing development of student who drew Figures 4, 17, 21. 
PROJECT \#1: INTRODUCTION OF CONTOUR DRAWING, "SELF PORTRAITS" USING GESTURE TO

EXPRESS MOOD

As some of the students were showing an interest in line, after the gesture drawings in the seventh week, I introduced contour drawing of positive and negative spaces. This was not well received. Although some of the work showed increased sensitivity, students stated that the technique took away the security they felt using the side of the charcoal, and revealed or even exaggerated their weaknesses. Although I had explained and demonstrated the disfointed quality of contour drawing, they rejected it in their own work, and were anxious to move on to the next part of the class. This began with a discussion of the ways people present themselves externally, and how this often differs from what they are actually feeling. Students became quite involved in the discussion. They felt comfortable personalizing the topic, and discussed their own feelings and behaviors. The assignment was for students to draw themselves as they appear, and as they feel, when both are different. They were encouraged to use the mirrors to arrive at characteristic postures. They were able to do this comfortably and avoided stereotypical Imagery. While no great gains were made in drawing skills, the project was meaningful to them in terms of gaining understanding of the significance of using subtle gestures to express the character of the subject. As Feldman wrote, "Facts do not automatically relate themselves to humanistic concerns; they must first 
be perceived in an affective context."10 Students were supportive of each other during this exercise, as demonstrated by empathetic remarks about each other's work. Because exploration of sensitive feelings can be threatening to adolescents a subject of this type would only be appropriate in a group having a high trust level, and a willingness to share feelings. Previous discussions and exercises had prepared this group for the experience. I would be very doubtful about introducing such a topic with a group of students I did not know well, with a group larger than fifteen, or with an incompatible group.

10E. B. Feldman, Becoming Human Through Art, p. 92. 


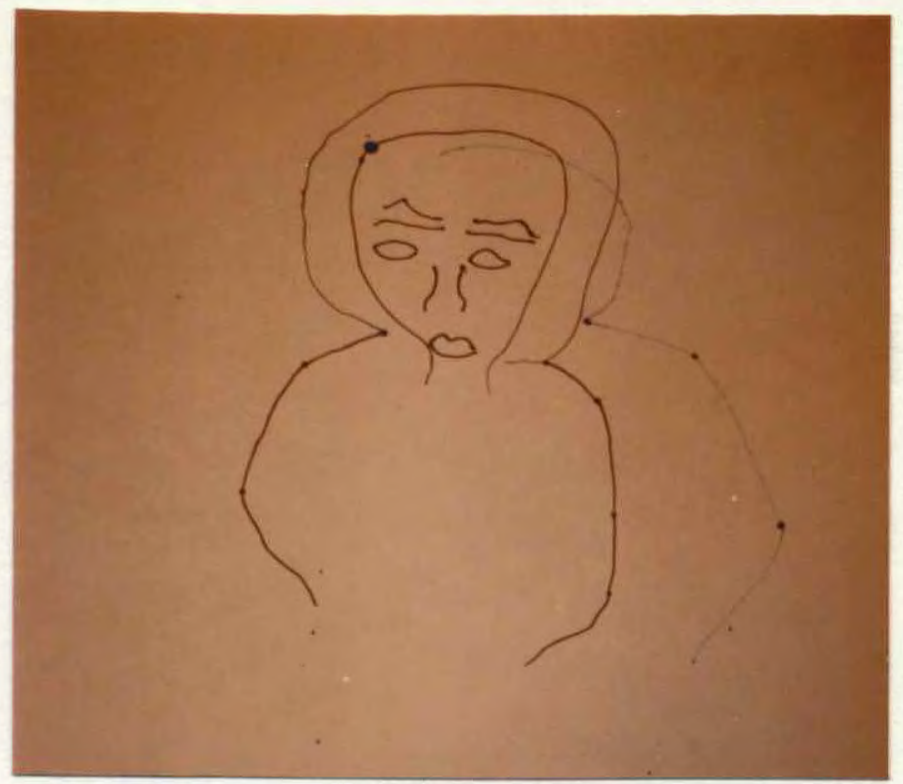

Figure 25. Contour drawing by student who drew Figure 23.

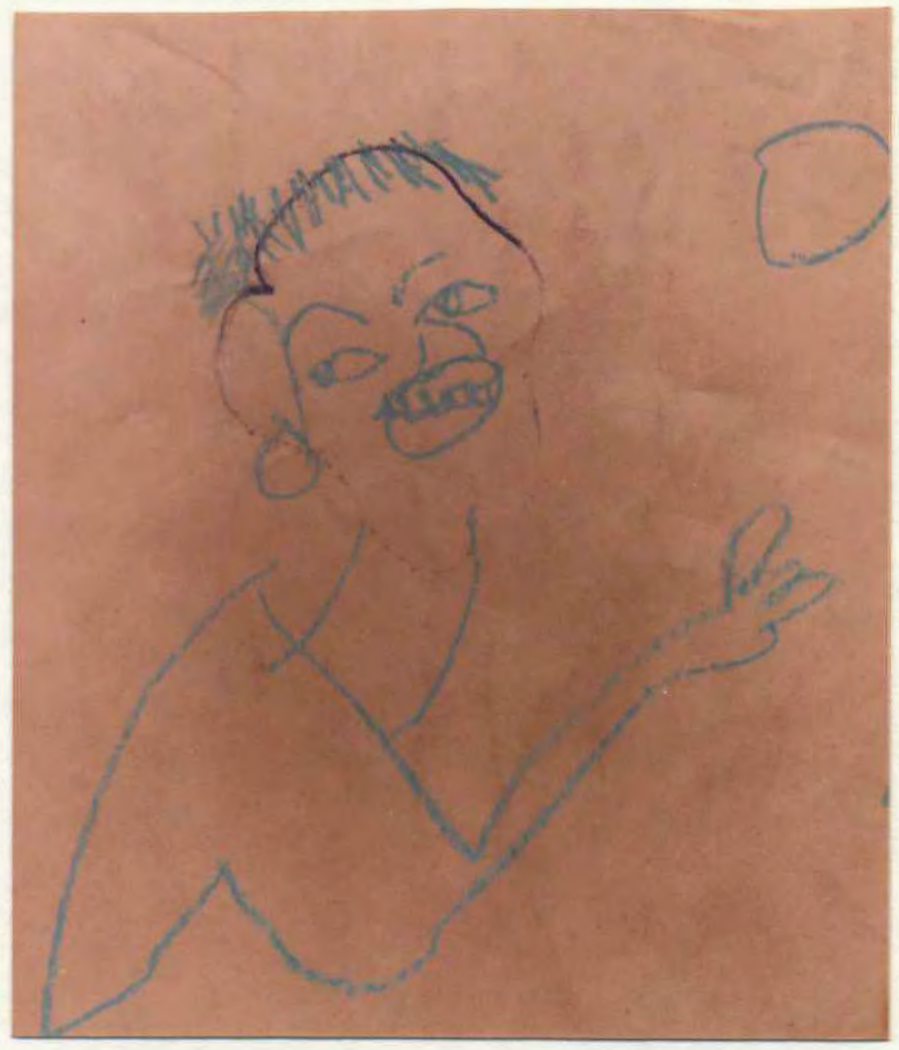

Figure 26. Contour drawing.

SOME RESULTS OF PROJECT 非, INTRODUCTION OF CONTOUR DRAWING 

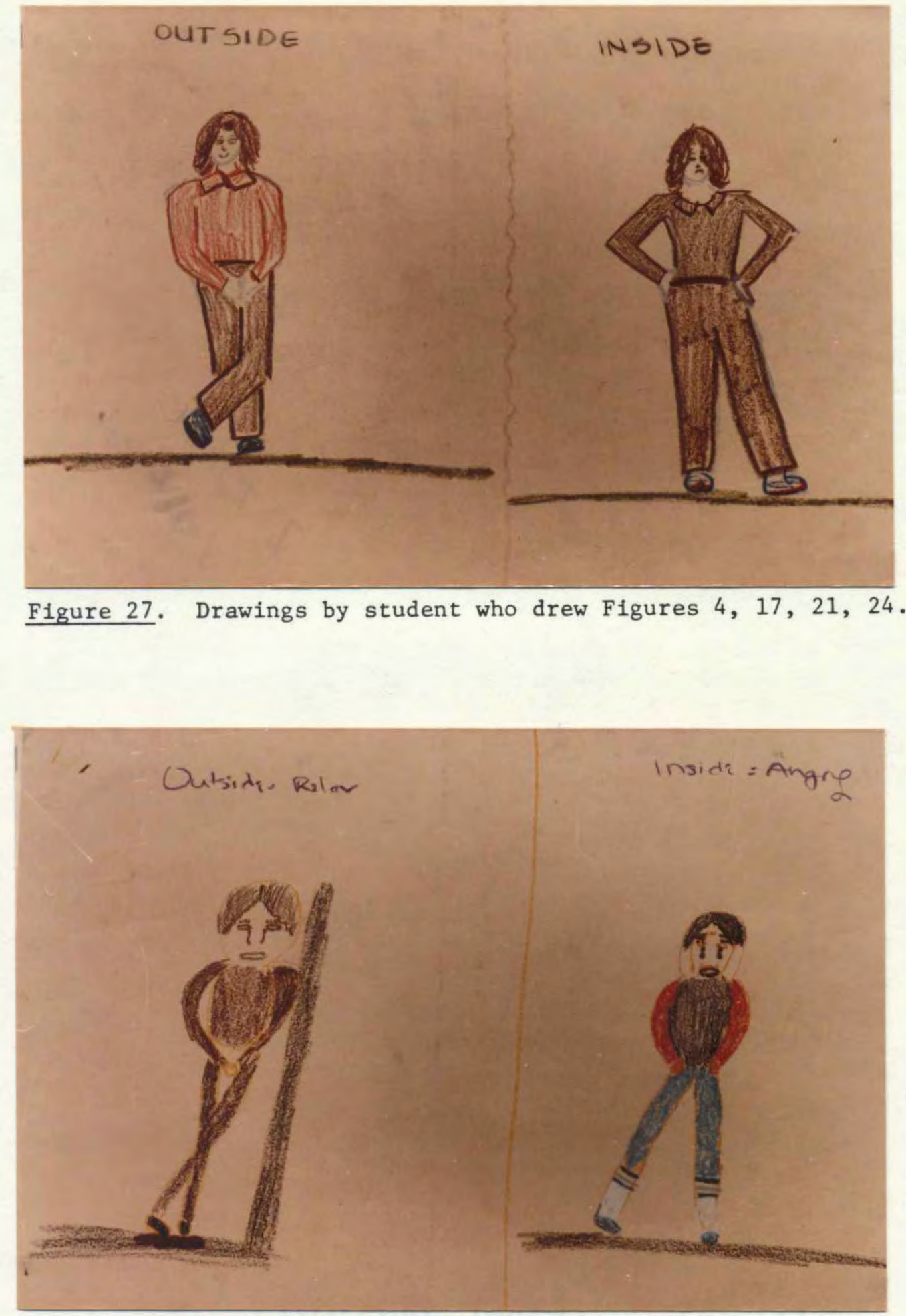

Figure 28. Drawings by student who drew Figures 23 and 25 .

SOME RESULTS OF PROJECT 非, "SELF PORTRAITS" USING GESTURE TO EXPRESS MOOD 


\section{PROJECT \#8: LIFE SIZED OUTLINE DRAWINGS, IMAGINATIVE COMPOSITIONS BASED ON \\ THESE DRAWINGS}

In the eighth week, in an effort to increase awareness of mass, to approach contour in a different way, and to stimulate students' Involvement through interaction, and creation of a novel self portrait, I began the class by assigning students partners. They took turns lying on sheets of butcher paper 42 inches wide, in positions which suggested movement. Their partners outlined their figures with marking pens. Each student painted his or her own outline drawing using tempera and large brushes. I encouraged them to use only one color each in order to keep the images simple. The paintings were hung on walls in the classroom. (Students were delighted with the results and brought friends to see them later in the day.) The next part of the assignment was to create compositions using the painted figures as models. Many of the students chose sports as their topic, as the movements in the figures suggested this. Some of the students preferred to work on paper larger than the 18 by 24 inch size they had been using. The project was helpful to the students. They were able to see the big shapes and movements clearly and without distracting details. Their work became bolder and more complex, often including groups of figures and retaining the strength and simplicity of the painted figures. 


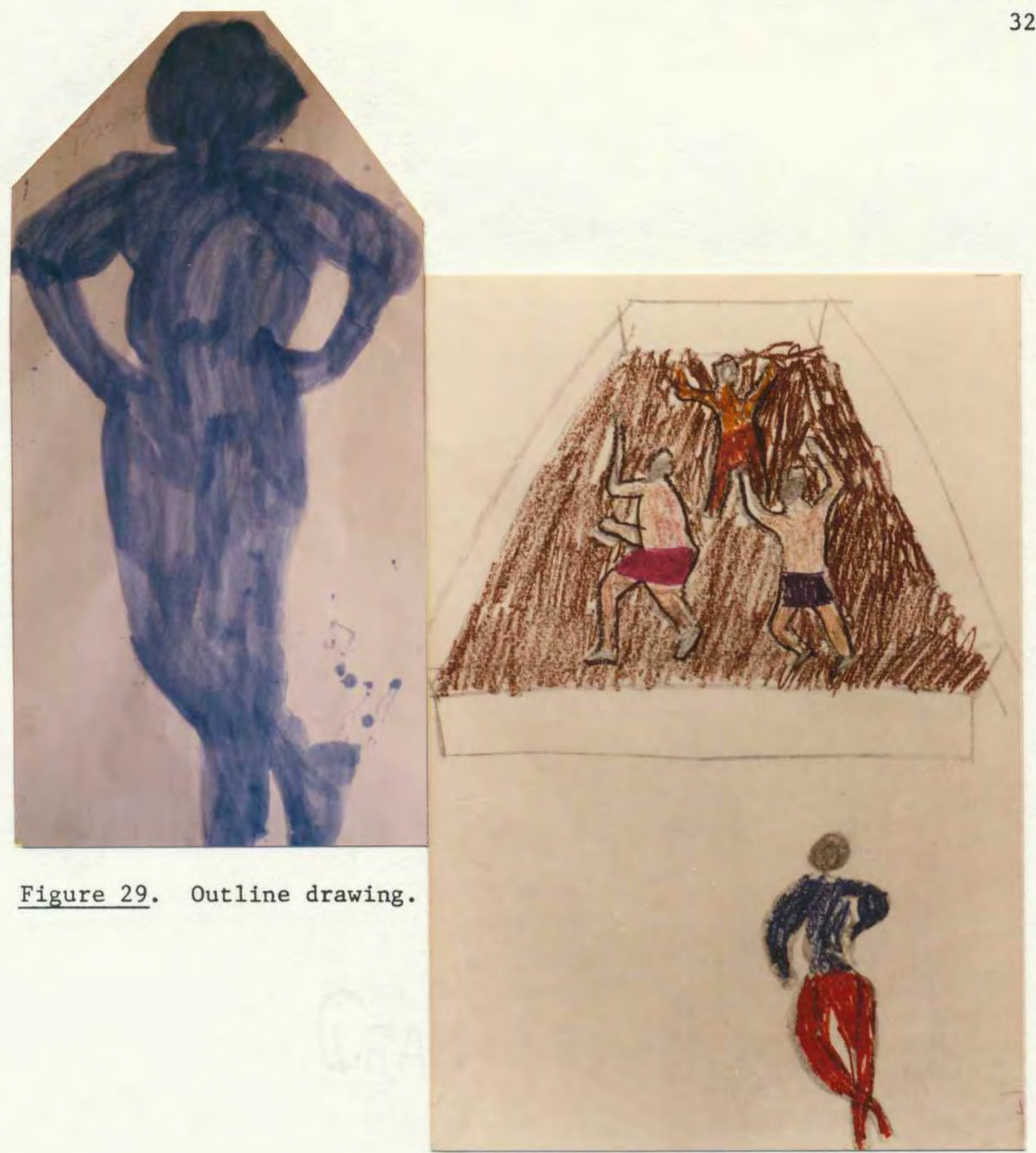

Figure 30. Composition by student who drew Figures 23, 25, 28. 


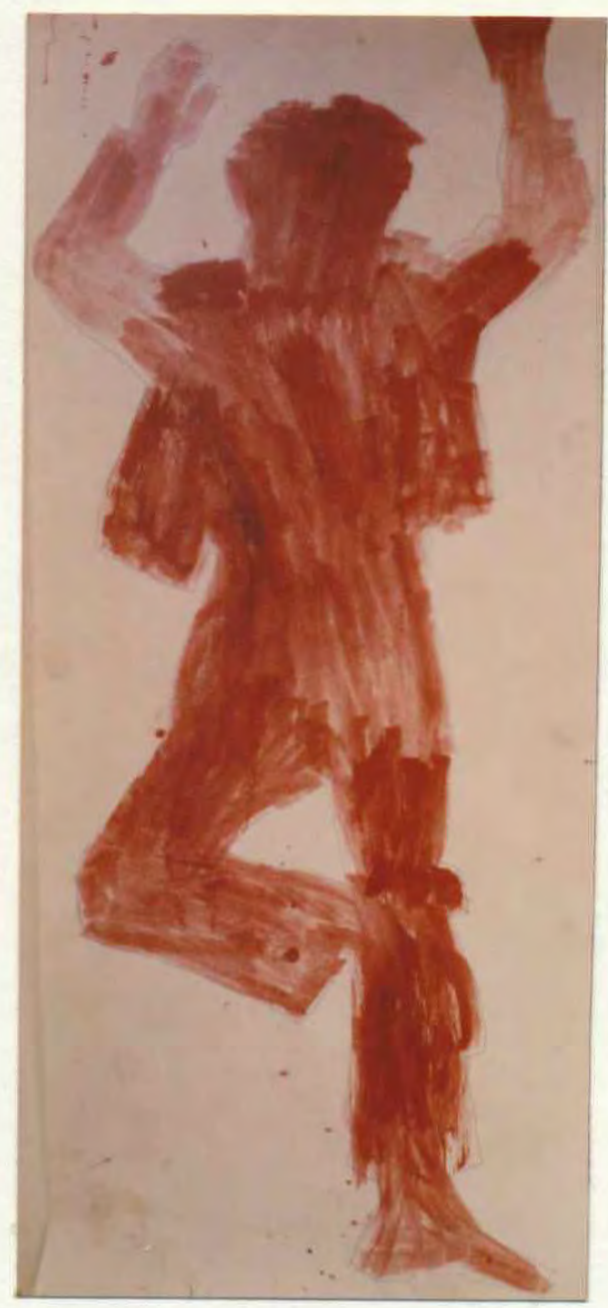

Figure 31. Outline drawing.

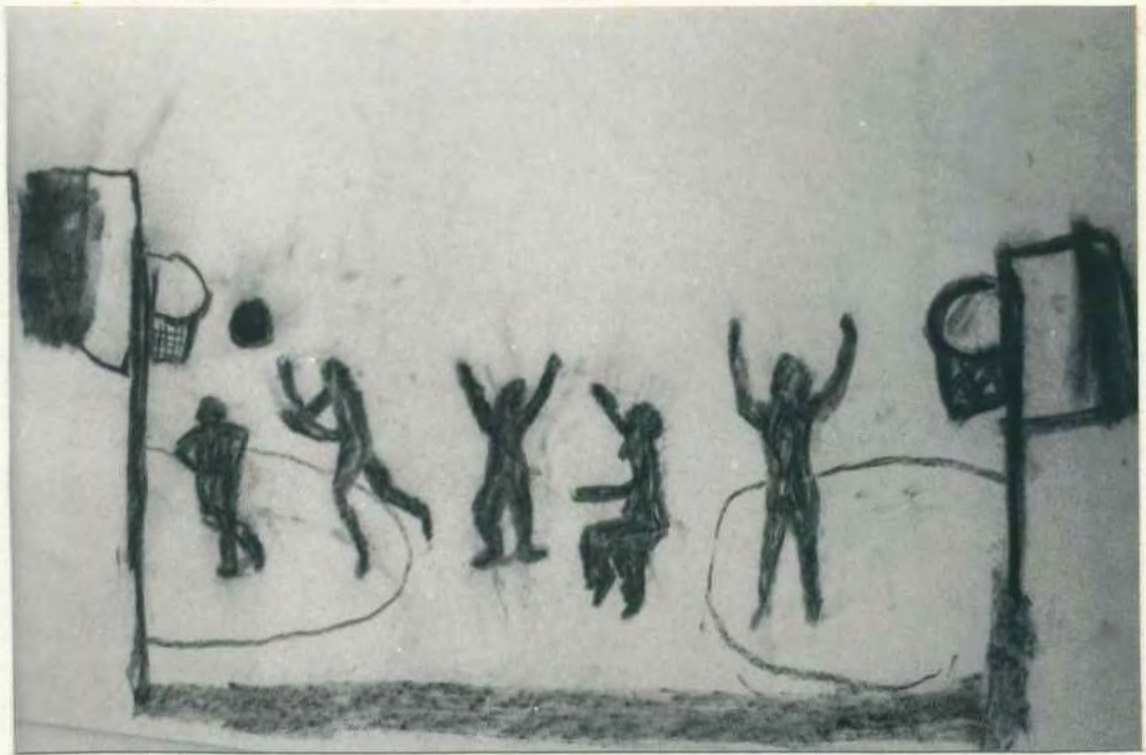

Figure 32. Composition by student who drew Figures 7, $8,13,15,16,19,22$.

SOME RESULTS OF PROJECT 非, LIFE SIZED OUTLINE DRAWINGS AND COMPOSITIONS BASED ON THESE DRAWINGS 
By this time students seemed to have become more relaxed about their work. They were able to be somewhat objective and critical about their own work and could accept compliments and criticism from peers. They showed interest in each other's progress and made remarks which Indicated an awareness of their own ability levels in relation to peers, however those with lesser abllities did not seem uncomfortable. Rather, each student expressed awareness of. the gains he or she had made, and seemed to have a sense of accomplishment. I attempted to foster this by perlodically bringing in an earlier drawing and remarking on the progress a particular student had made. 


\section{PROJECT \#9: CONTOUR DRAWINGS OF}

POSITIVE AND NEGATIVE SPACES

Because of the students' new self assurance, I thought we could concentrate during the last two weeks on drawing without using the context of an imaginative composition. In week nine, the model began by posing for gesture drawings within a square of masking tape attached to the wall. During the gesture drawings I pointed out the negative shapes as defined by the masking tape and the model. Then the model posed within the square for ten minutes. Students attempted contour drawings of positive and negative spaces. Then they did two fifteen minute drawings in which they could look at both the model and the page. The contour drawing technique was accepted readily by the majority of students at this point. It worked in terms of helping to keep the students focused on the model and drawing what they saw rather than what they thought was there. It also helped them develop some sensitivity to form and line. The students who began at the schematic stage had difficulty grasping the concept of positive and negative spaces. I encouraged them to continue working with the side of the charcoal, and do more lengthy gesture drawings. Using this technique they were able to produce work which showed what I thought to be remarkable progress in terms of understanding of proportions and movement. I found that working exclusively from the model without themes; worked for the more advanced students; however some others felt the need to continue with themes. Some students during this week were 
choosing a variety of media; others preferred to stay with charcoal and some continued to do their preliminary drawings in charcoal and to build upon them with other media. 


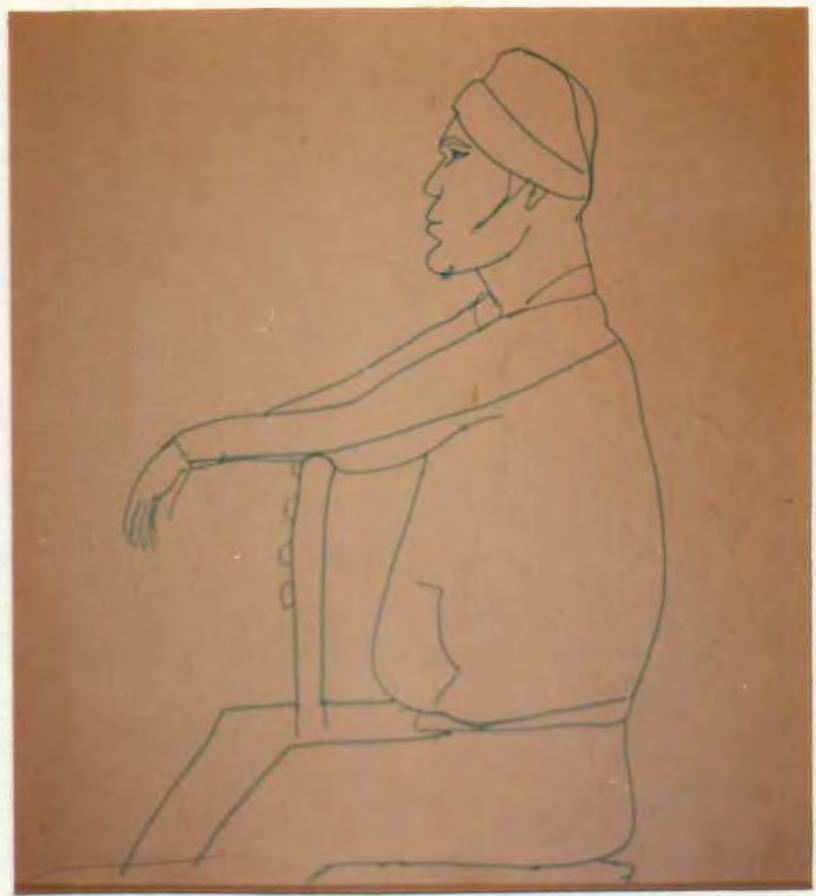

Figure 33. Contour drawing by student who drew Figures 4, 17, 21, 24, 27.

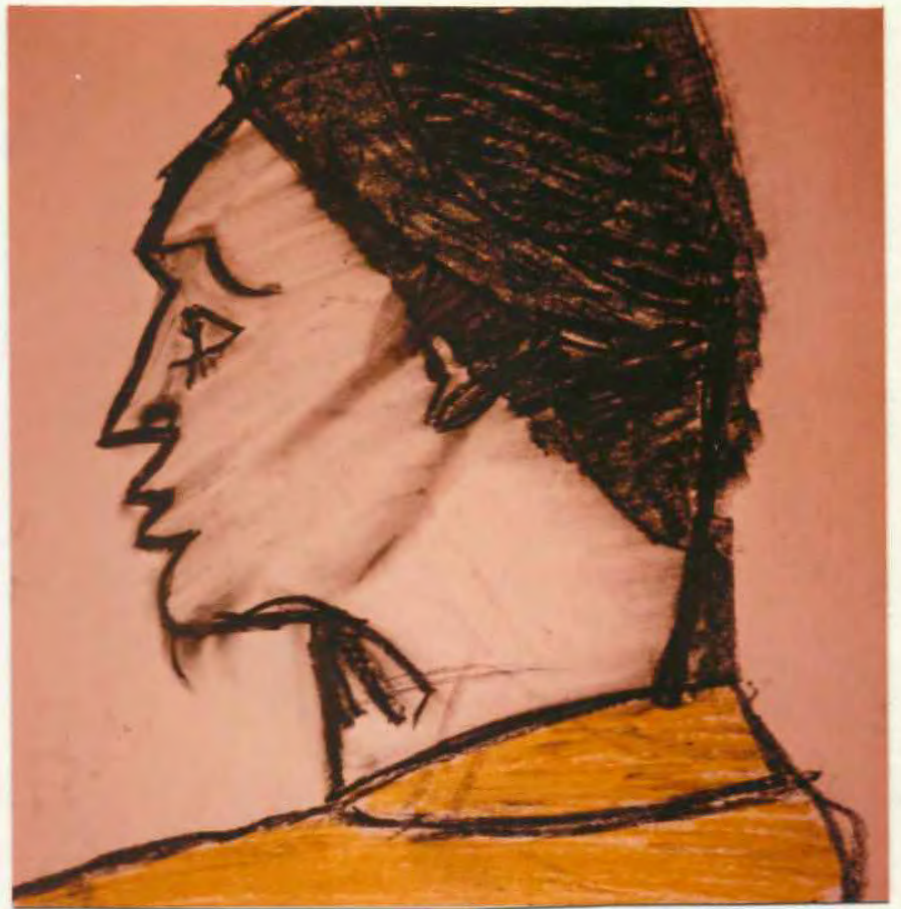

Figure 34 . Contour drawing by student who drew Figure 10.

SOME RESULTS OF PROJECT \# 9 , CONTOUR DRAWINGS OF POSITIVE AND NEGATIVE SPACES 


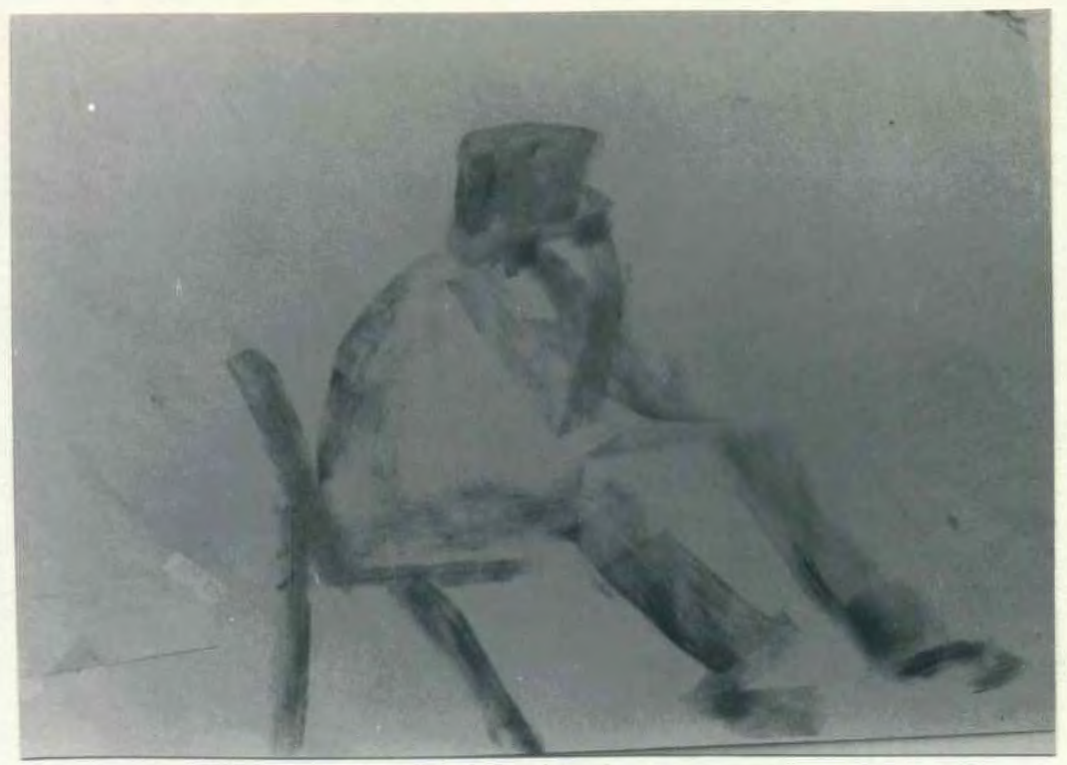

Figure 35. Gesture drawing by student who drew Figures 2 and 5 , showing development from schematic to "true to appearance" stage.

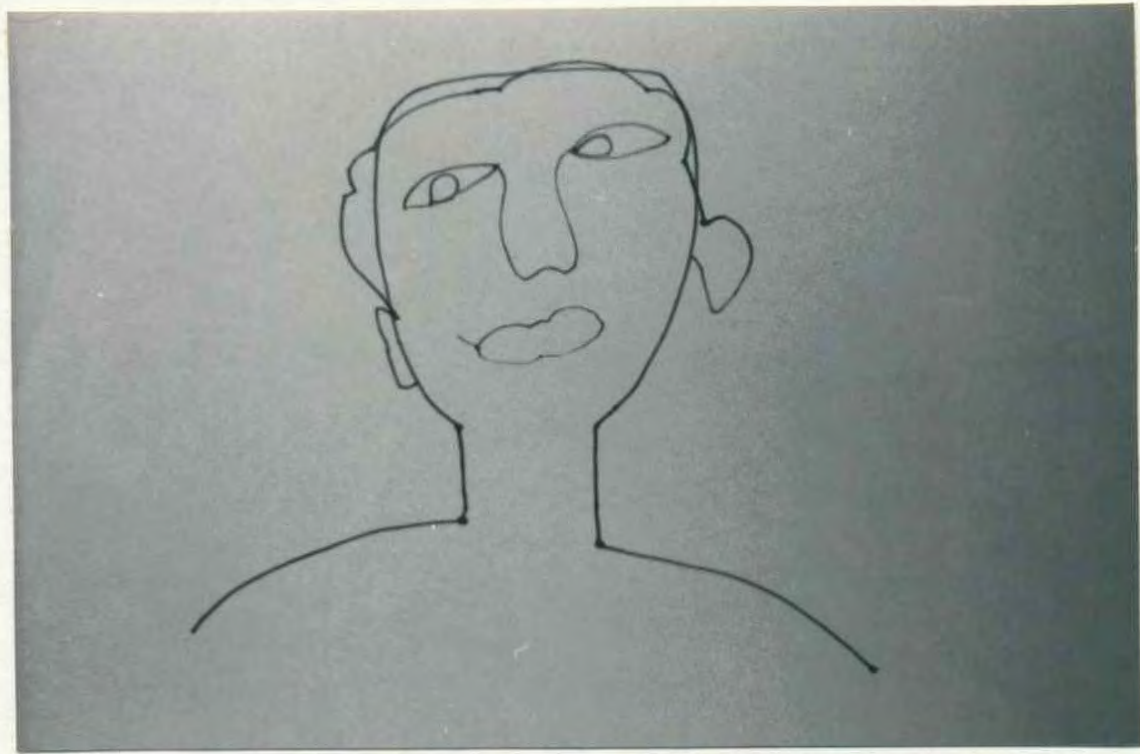

Figure 36. Contour drawing by student who drew Figures $2,5,35$, showing development from schematic to "true to appearance" stage.

SOME RESULTS OF PROJECT 非, CONTOUR DRAWINGS OF POSITIVE AND NEGATIVE SPACES 


\section{PROJECT \#10: COMBINED GESTURE}

AND CONTOUR DRAWINGS

In the final week, students began with gesture drawings of a model posing in costume with a guitar. She posed within the taped square. They selected the pose they perferred for a longer drawing. They began by doing charcoal gesture drawings upon which they superimposed line, using a contour drawing technique in which they looked at the model and the page. The initial gesture drawing helped them situate the figure on the page and adjust proportions using the familiar large mass approach. During the last twenty minutes of the class some of the more confident students chose to do drawings without the underlying charcoal sketches. The costume and prop seemed to capture the interest of all the students. The less advanced worked seriously throughout the period, continuing with gesture drawing techniques, and attempting to develop them. Some of them created imaginary compositions. The work completed this week showed increased confidence and visual perceptual skills. 


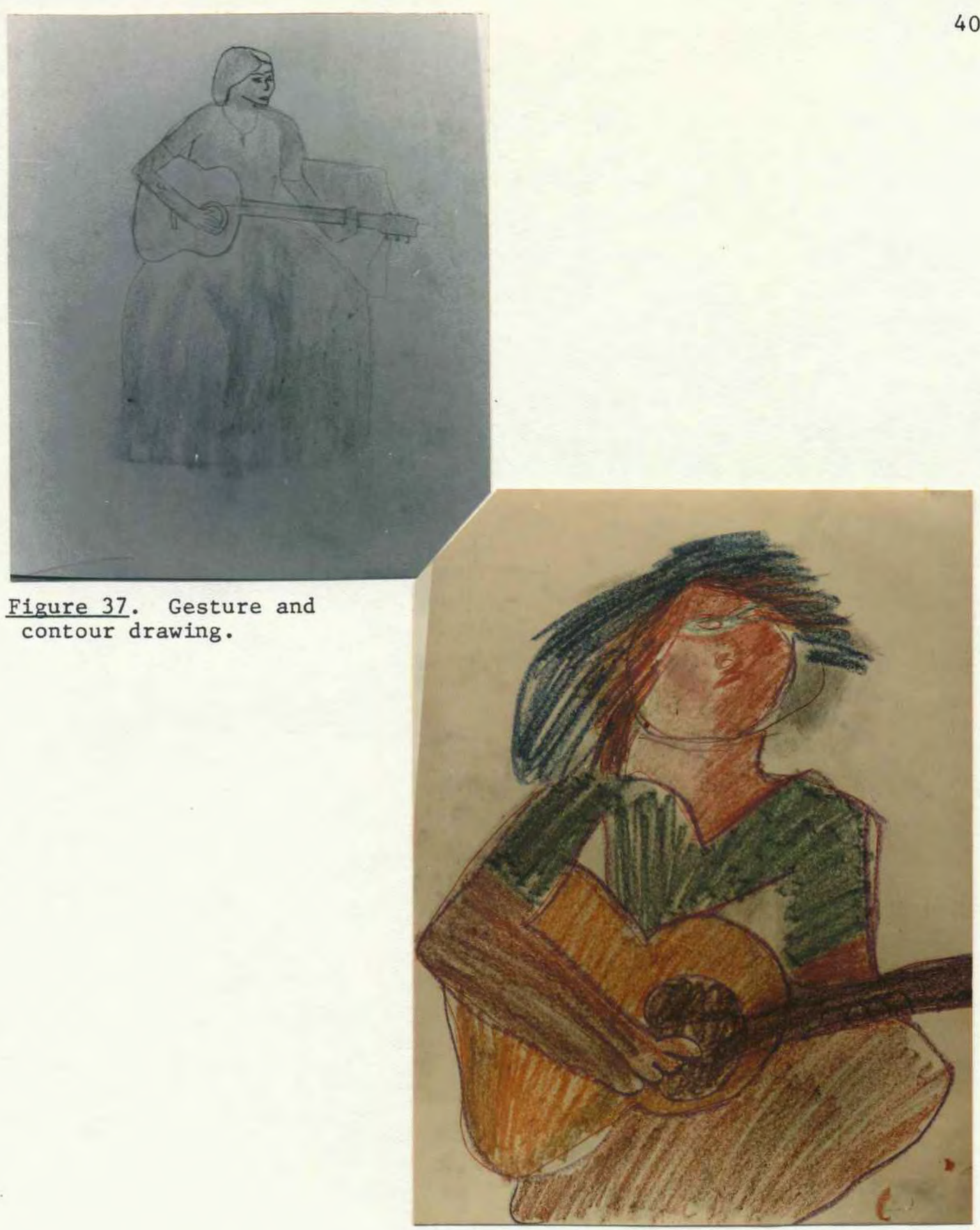

Figure 38. Drawing by student who drew Figures 10 and 34 .

SOME RESULTS OF PROJECT 非10, GESTURE AND CONTOUR DRAWINGS 


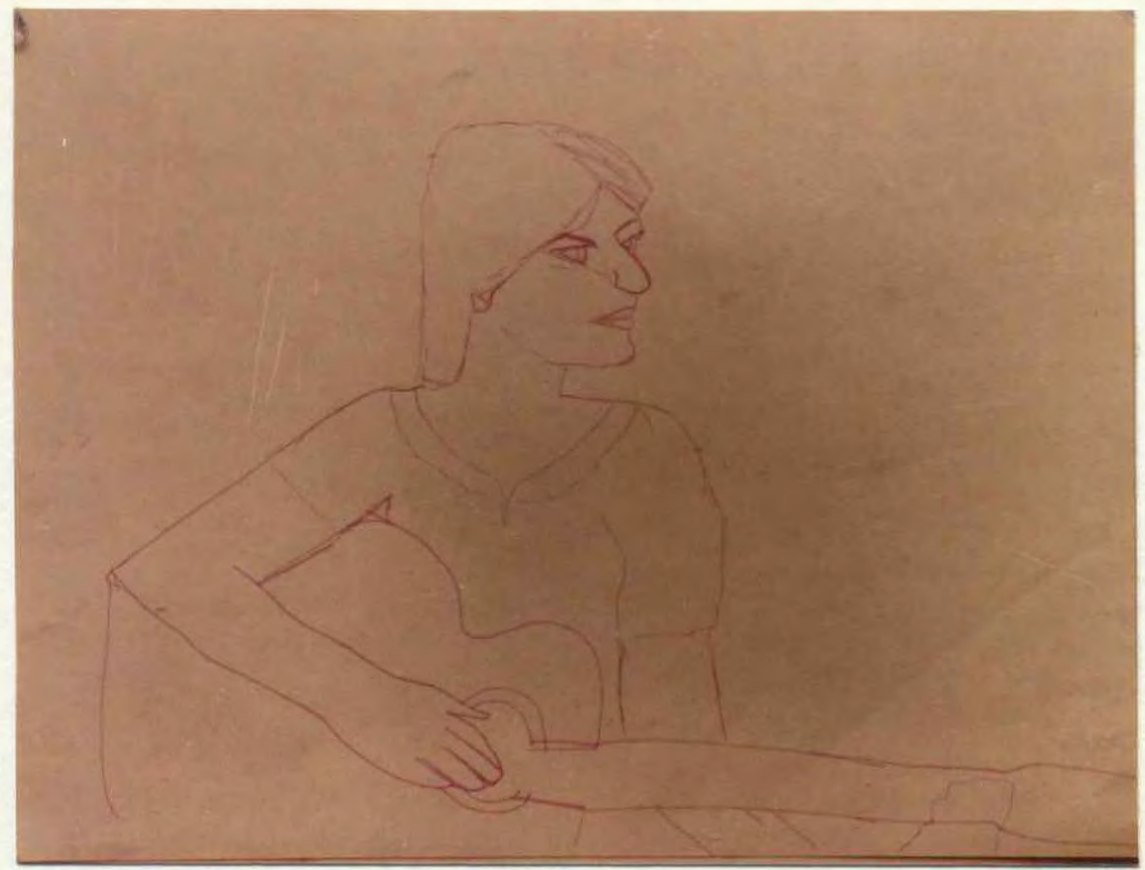

Figure 39. Drawing showing development of student who drew Figures 4, 17, 21, 24, 27.

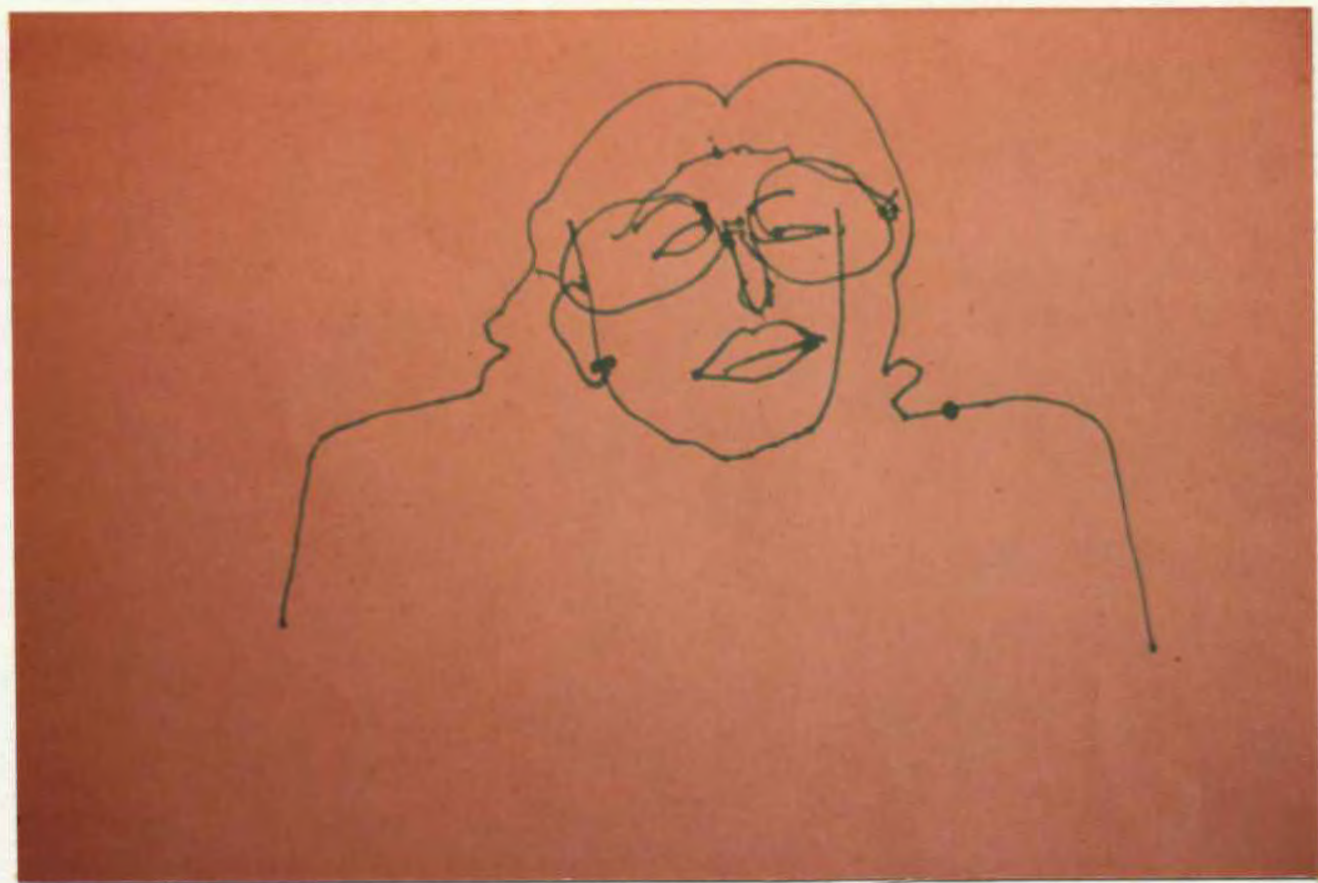

Figure 40. Drawing showing development of student who drew Figures 4, 17, 21, 24, 27, 39.

SOME RESULTS OF PROJECT 非10, GESTURE AND CONTOUR DRAWINGS 
CHAPTER III

CONCLUSIONS AND RECOMMENDATIONS

CONCLUSIONS

This research has convinced me that it is important when working with adolescents not to put too much emphasis in the beginning, on the technical problems involved in figure drawing. I think the student needs first to become aware of art as a valid and rewarding means of self exploration and communication. When that is internalized, and the student gains confidence in his or her abilities to use art in this meaningful way, the technical problems will be seen as a means to an end; the students will be more motivated to acquire the necessary skills, and will more readily grasp them. Dewey, in an essay on education states, "I think one could go through the defects and mistakes of teaching and learning generally, and find that they are associated with failure to secure emotional participation."11 In the figure drawing class emotional participation can be secured by directing the students towards relevant subject matter, by encouraging students to deal with affective responses to themes, and to look inward and explore more sensitive feelings. A method of increasing investment in

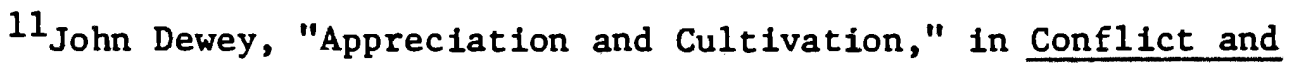
Continuity, A History of Ideas on Social Equality and Human Development, ed., John R. Snarey, Terrie Epstein, Carol Sienkiewicz and Philip Zodhiates, Repring Series No. 15, (Cambridge: Harvard Educational Review), 1981 . 
the group is to facilitate discussion of topics and of completed art. This technique helps to stimulate the imagination and build a cohesive, supportive group in which students feel that their opinions are valued. Using physical activities helps also. They develop body awareness, and empathy with the model, and add variety and stimulation.

As students become more confident and skilled in graphic representation of the figure, and more sensitive about interpreting their own work and the work of others, they will become aware that feelings are an intrinsic part of all art. They will understand that "Any drawing amounts to a positive affirmative statement, it both implies and illustrates the artist's conception of reality."12 When they understand that, the need for themes will decrease, and the student will be ready for the teacher to concentrate on the formal qualities and problems in the student's work, in order to help the student realize more effectively his or her conception of reality in graphic language. Some students may never achieve this awareness. In the group I worked with, one student verbalized an understanding of this concept.

\section{SUMMARY}

When I began this project I was interested in researching the effects on visual perceptual development, of a teaching approach designed to secure the students' emotional participation. I spent less time criticizing their work and suggesting changes than I would have done using a traditional figure drawing approach. However I found that

${ }^{12}$ Philip Rawson, Drawing, (New York: Oxford University Press), 1969, p. 19. 
students were more relaxed, interested, and receptive to suggestions, and progress in most cases was very rapid. I was particularly pleased with the development of the less talented students who began the class working at the schematic level. The students have sustained a high interest level in drawing the figure throughout the classes, and are eager to continue.

\section{RECOMMENDATIONS}

I recommend this approach to teachers who are introducing figure drawing to a group of adolescents of mixed ability levels, as it provides everyone with opportunities for success. It makes figure drawing less threatening, more personal and more fun. The students are working on that which they value most highly, the progress is clearly evident, and the rewards for the students are worthwhile. 


\section{A LIST OF WORKS CONSULTED}

Amheim, Rudolf. Visual Thinking. Berkeley and Los Angeles: University of California Press, 1969.

Betensky, Mala. Self Discovery Through Self Expression. Springfleld: Chas. C. Thomas, 1973.

Burkhart, Robert. Spontaneous and Deliberate Ways of Learning.

Scranton: International Text Book Co., 1962.

Conger, J. J. Adolescence and Youth. 2nd Edition, New York: Harper and Rowe, 1977.

Dewey, John. "Appreciation and Cultivation." In Conflict and Continuity, A History of Ideas on Social Equality and Human Development. Ed. John R. Snarey, Terrie Epstein, Carol Slenkiewicz and Philip Zodhiates. Reprint Series No. 15. Cambridge: Harvard Educational Review, 1981.

Edwards, Betty. Drawing on the Right Side of the Brain. Los Angeles:

J. P. Tarcher Inc., 1979 .

Feldman, E. B. Becoming Human Through Art. Englewood Cliffs: Prentice Hal1, 1971 .

Goldstein, Nathan. The Art of Responsive Drawing. Englewood Cliffs: Prentice Hall, 1973.

Figure Drawing. Englewood Cliffs: Prentice Hall, 1976.

Hoffman, Hans. Search for the Real. Cambridge: M.I.T. Press, 1967.

Kaufman, Irving. Art and Education in Contemporary Culture. New York: MacMillan, 1966.

Keiler, Manfred. The Art in Teaching Art. Lincoln: University of Nebraska, 1961 .

Lark-Horovitz, Betty, H1lda Lewis and Mark Luca. Understanding Children's Art for Better Teaching. Columbus: Chas. E. Merrill. 1973, 2nd ed.

Lowenfeld, Viktor. Creative and Mental Growth. New York: MacMillan, 1964, 2nd ed., 4th ed. 
National Art Education Association. Art Education: Senior High School. Reston: N.A.E.A., 1972 .

Rawson, Philip. Drawing. New York: Oxford University Press, 1969.

Reed, Herbert. Education Through Art. 3rd ed. London: Faber and Faber, 1956 .

Rhyne, Janie. The Gestalt Art Experlence. Monterey: Brooks/Cole, 1963. 


\section{APPENDIX}

LIST OF FIGURES

PAGE

Figure 41

Drawing by the Author ................

Figure 42

Drawing by the Author . . . . . . . . . . . .

Figure 43

Drawing by the Author ................

Figure 44

Drawing by the Author . . . . . . . . . . . . 

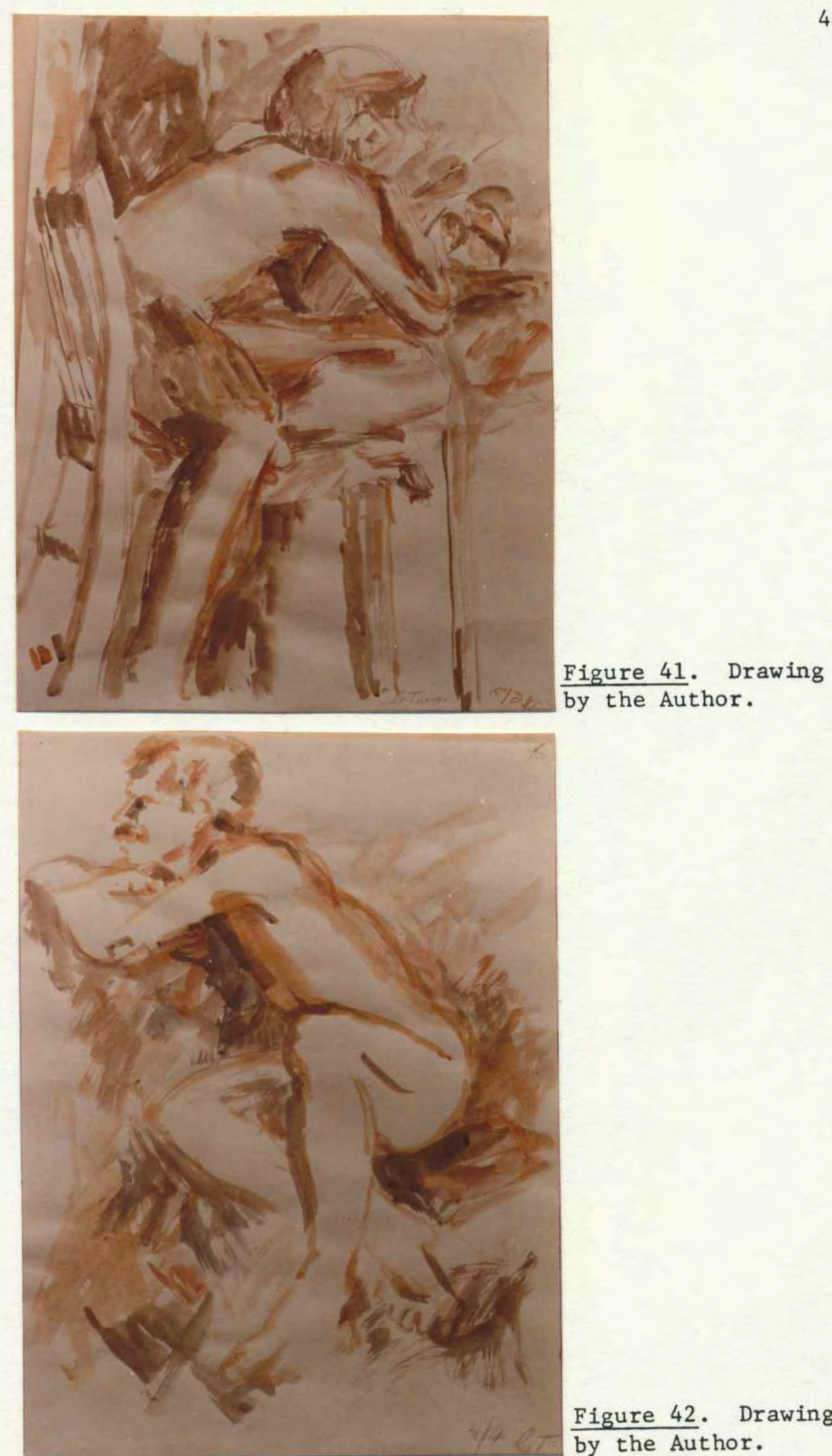

Figure 42. Drawing by the Author. 


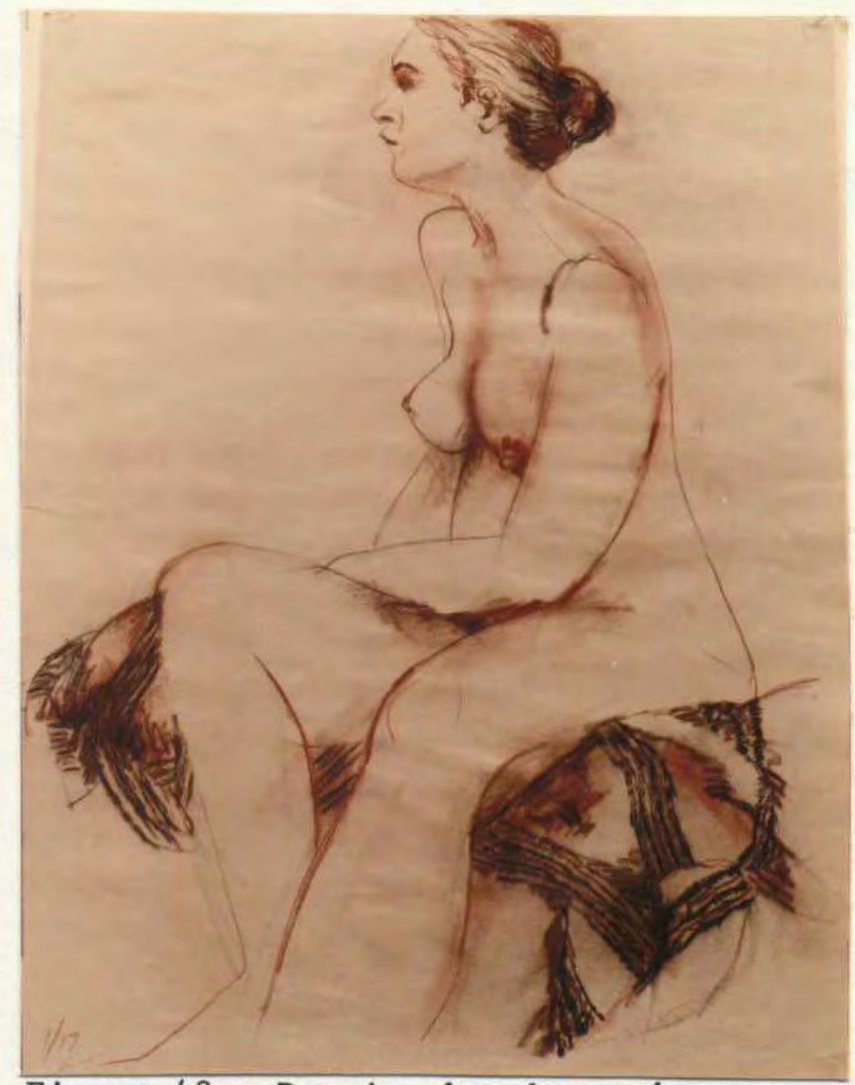

Figure 43 . Drawing by the author.

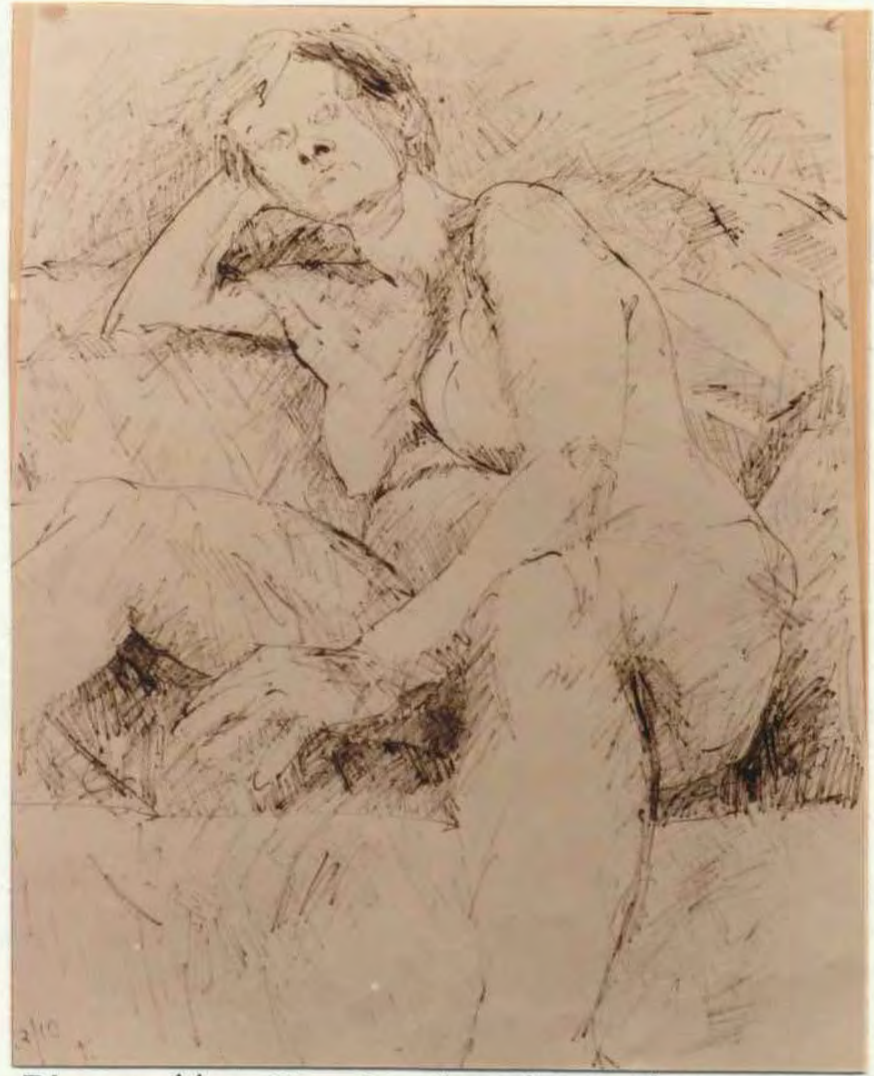

Figure 44. Drawing by the author. 